\title{
A Role for Extracellular Vesicles in SARS-CoV-2 Therapeutics and Prevention
}

\author{
Jatin Machhi ${ }^{1}$ - Farah Shahjin ${ }^{1}$. Srijanee Das ${ }^{2}$. Milankumar Patel ${ }^{1} \cdot$ Mai Mohamed Abdelmoaty ${ }^{3,4}$ - Jacob D. Cohen ${ }^{1}$. \\ Preet Amol Singh ${ }^{5}$ - Ashish Baldi ${ }^{5} \cdot$ Neha Bajwa $^{5} \cdot$ Raj Kumar $^{6}$ - Lalit K. Vora ${ }^{7} \cdot$ Tapan A. Patel $^{8} \cdot$ Maxim D. Oleynikov $^{1}$. \\ Dhruvkumar Soni $^{3}$ - Pravin Yeapuri ${ }^{1}$. Insiya Mukadam ${ }^{3}$ - Rajashree Chakraborty ${ }^{1}$. Caroline G. Saksena ${ }^{1}$. \\ Jonathan Herskovitz ${ }^{2} \cdot$ Mahmudul Hasan $^{3}$. David Oupicky ${ }^{6}$. Suvarthi Das ${ }^{9} \cdot$ Ryan F. Donnelly ${ }^{7} \cdot$ Kenneth S. Hettie $^{10}$. \\ Linda Chang ${ }^{11} \cdot$ Howard E. Gendelman ${ }^{1,5}$ (D) Bhavesh D. Kevadiya ${ }^{1}$
}

Received: 18 December 2020 / Accepted: 28 December 2020/Published online: 5 February 2021

(C) The Author(s), under exclusive licence to Springer Science+Business Media, LLC part of Springer Nature 2021

\begin{abstract}
Extracellular vesicles (EVs) are the common designation for ectosomes, microparticles and microvesicles serving dominant roles in intercellular communication. Both viable and dying cells release EVs to the extracellular environment for transfer of cell, immune and infectious materials. Defined morphologically as lipid bi-layered structures EVs show molecular, biochemical, distribution, and entry mechanisms similar to viruses within cells and tissues. In recent years their functional capacities have been harnessed to deliver biomolecules and drugs and immunological agents to specific cells and organs of interest or disease. Interest in EVs as putative vaccines or drug delivery vehicles are substantial. The vesicles have properties of receptors nanoassembly on their surface. EVs can interact with specific immunocytes that include antigen presenting cells (dendritic cells and other mononuclear phagocytes) to elicit immune responses or affect tissue and cellular homeostasis or disease. Due to potential advantages like biocompatibility, biodegradation and efficient immune activation, EVs have gained attraction for the development of treatment or a vaccine system against the severe acute respiratory syndrome coronavirus 2 (SARS CoV-2) infection. In this review efforts to use EVs to contain SARS CoV-2 and affect the current viral pandemic are discussed. An emphasis is made on mesenchymal stem cell derived EVs' as a vaccine candidate delivery system.
\end{abstract}

Keywords Extracellular vesicles (EVs) - Mesenchymal stem cells (MSCs) - Severe acute respiratory syndrome coronavirus 2 (SARS-CoV-2) · Coronavirus disease 2019 (COVID-19)

Howard E. Gendelman

hegendel@unmc.edu

1 Department of Pharmacology and Experimental Neuroscience, College of Medicine, University of Nebraska Medical Center, Omaha, NE 68198-5880, USA

2 Department of Pathology and Microbiology, College of Medicine, University of Nebraska Medical Center, Omaha, NE 68198, USA

3 Department of Pharmaceutical Sciences, College of Pharmacy, University of Nebraska Medical Center, Omaha, NE 68198, USA

4 Therapeutic Chemistry Department, Pharmaceutical and Drug Industries Research Division, National Research Centre, Giza, Egypt

5 Department of Pharmaceutical Sciences \& Technology, Maharaja Ranjit Singh Punjab Technical University, Bathinda, PB, India
6 Center for Drug Delivery and Nanomedicine, Department of Pharmaceutical Sciences, University of Nebraska Medical Center, Omaha, NE 68198, USA

7 School of Pharmacy, Queen's University Belfast, 97 Lisburn Road, Belfast BT9 7BL, UK

8 Department of Biological Sciences, P. D. Patel Institute of Applied Sciences (PDPIAS), Charotar University of Science and Technology (CHARUSAT), Changa, Anand, Gujarat 388421, India

9 Department of Medicine, Stanford Medical School, Stanford University, 94304 Palo Alto, CA, USA

10 Molecular Imaging Program at Stanford (MIPS), Department of Radiology, Department of Otolaryngology - Head \& Neck Surgery, Stanford University, 94304 Palo Alto, CA, USA

11 Departments of Diagnostic Radiology \& Nuclear Medicine, and Neurology, School of Medicine, University of Maryland, 21201 Baltimore, MD, USA 


\section{Introduction}

Following the emergence of the severe acute respiratory syndrome coronavirus 2 (SARSCoV-2) in late 2019 global spread become rapid and significant leading to the social, personal, societal and financial devastations of coronavirus disease 2019 (COVID-19) (Li et al. 2020a; Machhi et al. 2020). Despite the impact of the global pandemic that rapidly followed its origins in Wuhan, China efforts to find effective diagnostics, medicines, societal intervention and a curative vaccine have purposely led to problem solutions. Repurposed antiviral drugs and immunomodulating agents while variably effective for disease management, an effective vaccine as a final preventive measure has only within the last weeks come available (Corey et al. 2020; Thanh Le et al. 2020). To the credit of the scientific and governing communities in the United States of America (USA) and abroad vaccine candidates have come available with parallel clinical testing throughout the world. A number of vaccine platforms of which several have not been used previously are marketed and safe. At the forefront is BNT162b2 is a messenger RNA (mRNA) nanovaccine, developed jointly by Pfizer and BioNTech, has already received emergency use authorization in the UK, UAE and USA (US FDA 2020; Pharmaceutical Business Review, 2020). The nanocarrier based delivery systems such as microparticles and nanoparticles have gained significant interest recently following promising clinical outcomes (Singh et al. 2007). Yet another completed in parallel studies has come available through Moderna's mRNA-1273 SARS-CoV-2 vaccine (Moderna, 2020). These complement a broad range of viral antigen delivery systems developed by a broad net of pharmaceutical companies and academic institutions (ContagionLive, 2020; Corey et al. 2020). However, despite the advantage of antigens the lead use of particle delivery can be limiting for both immune reactions and sustained efficacy. Particle deliver system pose concerns as they themselves are immunogenic in nature and any use to boost responses through adjuvants used in formulation may not be consistent amongst persons and the long-term efficacy remains ill defined (Chung et al. 2020; Liu et al. 2020).

With these limitations in mind newer types of carriers have been devised. One at the forefront of development are extracellular vesicles (EVs) (O'Driscoll, 2020; Pocsfalvi et al. 2020). They have gained considerable attention based on their natural biocompatibility and defined effectiveness as therapeutic and disease preventative agents in parallel microbial systems (Raposo and Stoorvogel, 2013; Pitt et al. 2016). For example, mesenchymal stem cells (MSCs) and their EVs have been investigated into the different clinical studies of COVID19 due to their ability to interact different innate and adaptive immune cells (Fig. 1) (O’Driscoll, 2020; Shu et al. 2020). EVs are generated by most of the living cells, contain proteins, nucleic acid, and lipids, and housed in spherical bilayer proteolipids with a size ranging from 20 to $4000 \mathrm{~nm}$. (Gao et al. 2020a). Based on such biocompatibility, EVs show feasibility to enclose immune modulating candidates to stimulate antigen-specific immune responses. EVs are present in blood, plasma, serum, saliva, urine, breast milk, and have been identified to affect a range of physiological and pathophysiological conditions (S et al. 2013; Yanez-Mo et al. 2015). Thus, EVs can be used in the diagnosis, treatment and prevention of disease (Fuhrmann et al. 2015; Ku et al. 2018).

EVs are of several types. This includes exosomes, microvesicles (MVs), retrovirus-like particles (RLPs), and apoptotic bodies (ABs). The classification is based on their origin and size, and thus each subclass of EVs has specific physicochemical properties. EVs are natural carriers in the human body and are engaged in cell-to-cell communications (Thery et al. 2018). Exosomes are formed within the endosomal network. Endosomes target some proteins and lipids for lysosomal degradation while targeting others for recycling or exocytosis. The late endosomes either fuse with lysosomes or the plasma membrane resulting in the secretion of $30-100 \mathrm{~nm}$ diameter-sized vesicles (exosomes) into the extracellular space (Akers et al. 2013). MVs tend to be larger in size (50$2000 \mathrm{~nm}$ ) relative to exosomes. Although the size ranges overlap between these two types of vesicles, the mechanism of biogenesis of exosomes is distinct from that of MVs which arise through direct outward budding and fission of the plasma membrane. The term "ectosomes" has also been coined to describe MVs. The microvesicular formation is a result of the dynamic interplay between phospholipid redistribution and cytoskeletal protein contraction (Stein and Luzio, 1991; Hess et al. 1999). RLPs are $90-100 \mathrm{~nm}$ in size and are noninfectious vesicles that resemble retroviral particles, and RLPs are released from cells after the viral infection. The most widely accepted for RLP formation involves the interaction of retroviral proteins, such as Gag, with components of the plasma membrane, and cytoskeletal proteins (Gladnikoff et al. 2009; Pincetic and Leis, 2009; Schwab et al. 2015). In this case, RLPs contain retroviral proteins, but they are non-infectious because they do not contain the full complement of genes required for cellular entry or viral propagation. There are some speculations that RLPs arise from a transcription of human endogenous retrovirus sequences (HERV). Approximately $8 \%$ of the human genome is made up of endogenous retroviral sequences. The HERVs are grouped into families annotated by letters (i.e., HERV-A, B, C, and etc.). Of these, the HERV$\mathrm{K}$ family is the only one that contains open reading frames for functional retroviral proteins Gag, Env, Rec, and Pol (Barbulescu et al. 1999; Bock and Stoye, 2000). Though the expression of the HERV-K genes is generally repressed (Yoder et al. 1997; Florl et al. 1999), de-repression occurs during cellular stress that include radiation, chemical treatment, cytokine and hormone stimulation, or oncogenic 


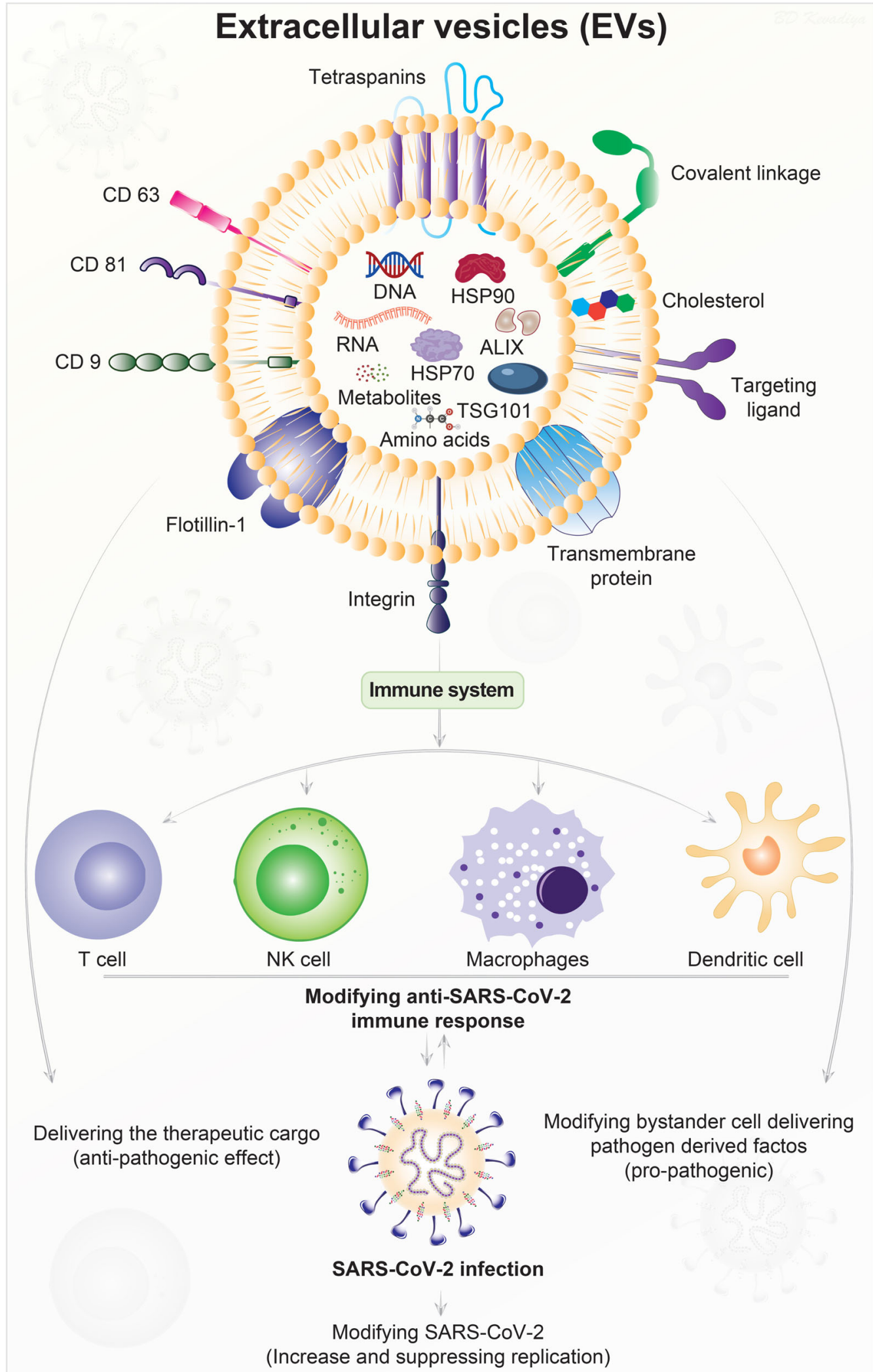

Fig. 1 EVs can facilitate antiviral immune responses. The exosome cargo consists of biomolecules including proteins, lipids, nucleic acids and metabolites. Each of these are either on the cell membrane or in an intravesicular compartment. Exosomes can interact with the immune cells, such as T-cells, NK-cells, macrophages, and dendritic cells, to modulate antiviral immune responses including against SARS-CoV-2. Exosomes can also exert "killing" effects on infected cells as well as delivery of viral pathogen-derived antigens. Exosomes, through loading therapeutic cargo, can be used for deployment of vaccines or therapeutic agents to generate robust antiviral immunity 
transformation (Taruscio and Mantovani, 2004; Golan et al. 2008; Reiche et al. 2010). The size overlap between exosomes, MVs, and RLPs makes it difficult to separate RLPs from the other two types of EVs when RLPs are secreted from the cells at the same time (Akers et al. 2013). ABs or apoptosomes originate from the process of cell death "apoptosis" through several stages, commencing from the condensation of the nuclear chromatin, followed by membrane blebbing, and progressing to the disintegration of the cellular content into distinct membrane enclosed vesicles (Yanez-Mo et al. 2015; Battistelli and Falcieri, 2020). Whereas exosomes, MVs, and RLPs are secreted during normal cellular processes, $\mathrm{ABs}$ are formed only during programmed cell death. ABs are generally larger in size $(500-4000 \mathrm{~nm})$ than the other types of EVs are characterized by the presence of organelles in the vesicle itself (Hristov et al. 2004; Elmore, 2007).

\section{Intercellular Communication}

The human immune response involves rapid cell-cell communication to protect the body from invading pathogens. One of the many ways by which cells communicate to each other is via EVs (Robbins and Morelli, 2014; Yanez-Mo et al. 2015). EVs are produced by most nucleated cells and their composition differs based on the physiological and pathological conditions. Hence, they can be derived either from the pathogen or the host (Crenshaw et al. 2018). EVs have very important roles in cellular function and disease. Their complex composition enables precise control during cell-cell communication. EVs can interact with range of innate and adaptive immune cells including T-cells, NK-cells, macrophages, and dendritic cells due to multi-valent receptor nanoassembly and therefore regulate downstream signaling pathways (Robbins and Morelli, 2014; Yanez-Mo et al. 2015). They can also act as carriers of signaling lipids, proteins, and RNA, thereby resulting in a marked response from the target cell (Shahjin et al. 2019). When released, these vesicles can be "captured" by host cells, which triggers transferring of viral proteins or inhibiting an immune response via (i) induction of apoptosis or (ii) blocking key cellular responses. Hence, EVs have a potential advantage for use in vaccine therapies, as they (i) are the body's natural antigen carriers and can circulate throughout body fluids to distribute antigens even to distal organs, (ii) can maintain stable protein structures, and (iii) bind and enter antigen presenting cells (APCs) as they express adhesion molecules on their surface (Schorey and Harding, 2016). All these properties make EVs a potential candidate for the treatment of SARS-CoV-2 infection. Figure 1 illustrates the EVs interactions with immunocytes and their ability to deliver pathogenic and therapeutic cargos to induce diverse immune responses against SARS-CoV-2.
EVs are known to participate in transmitting information from the source cell to a neighbor recipient cell by two possible mechanisms. The first potential mechanism involves EVs binding with specific receptors and/or adhesion molecules, such as integrins (Hoshino et al. 2015), lectins (Barres et al. 2010), proteoglycans (Christianson et al. 2013), and tetraspanins (Mulcahy et al. 2014). After binding to the cell surface, internalization of EVs in receiver cells takes place by processes like endocytosis, including micropinocytosis and phagocytosis. Endocytosis can take place through clathrindependent (Tian et al. 2014) and/or -independent pathways (Costa Verdera et al. 2017). The second mechanism involves a direct fusion of EV membrane with the plasma membrane and subsequent release of exosomal content in the cell cytoplasm (Montecalvo et al. 2012). Vacuoles formed during micropinocytosis for ingestion of extracellular liquid by the protrusion of plasma membrane also include EVs of smaller size (Feng et al. 2010). Larger size EVs are internalized through receptor-mediated phagocytosis by macrophages (Barres et al. 2010). Phosphatidylserine (PS) plays an important role by being present on the exterior of EV membrane and its subsequent binding with PS receptors present on the macrophage's surface. However, the most essential step to ascertain cellular communication and transportation of signaling molecules through EVs is delivery of the EV content after internalization (Montecalvo et al. 2012). The ability of EVs to transfer genetic information is also evident from its capacity to carry different types of nucleic acid, namely miRNA, circRNA, and IncRNA (Pegtel et al. 2010; Yu et al. 2016; Bhome et al. 2018; Hinger et al. 2018). EVs are also a means for horizontal gene transfer, as evident from the presence of DNA, such as mtDNA on the outer side of the vesicle (Kawamura et al. 2017) and dsDNA in the cytoplasm (Vagner et al. 2018).

In contrast to homeostatic conditions, the communication of transfectivity occurs during viral infection. Many studies have shown that EVs from infected cells can carry viral components that contribute to the spread of the pathogenesis by accelerating viral entry to escape immune cell recognition (Yogev et al. 2017; Patters and Kumar, 2018; McNamara et al. 2019; Hassanpour et al. 2020). Both virus and EVs are postulated to share converging pathways in terms of their transmission, biogenesis, and release of virions and viruslike proteins in recipient cells. Both virus and EVs also share the same biochemical properties, structural motifs, and size, to a particular extent (Kawamura et al. 2017; Crenshaw et al. 2018). Thus, EVs produced from virus-infected cells act as important mediators in both viral infection as well as antiviral response, depending on the internalized moiety. EVs can modulate the immune response of the host due to encapsulation of infectious virions, viral elements, defective viral particles, viral proteins, and nucleic acids of viral origin (RaabTraub and Dittmer, 2017; Urbanelli et al. 2019). 
EVs are crucial players in immunopathogenesis owing, in part, to the multiplicity of signaling changes that they trigger in their target cells (S et al. 2013). MVs' function is source- or stimulus-dependent and likely to be primarily either pro- or anti-inflammatory. Thus, MVs became progressively recognized as active players in immune complications of infectious diseases (Delabranche et al. 2012; Schorey and Harding, 2016). Many studies have shown the role of MVs to be that of immunopathologic mediators, notably by assisting in the binding of infected erythrocytes to the cerebral vasculature and mediating numerous inflammatory and immune processes (Wassmer et al. 2011). Furthermore, to this adjuvant role in cytoadherence, MVs, in infectious diseases, can deliver antigen, derived from the biological cargo acquired from their cells of origin to APCs (Ling et al. 2011). In the context of brain diseases, MVs appear to be one of many modes of cellcell communication between brain endothelium and astrocytes; as the interactions between the various components of the blood-brain barrier involves MVs and the kynurenine pathway (Combes et al. 2012; Fruhbeis et al. 2013). Regulatory $\mathrm{T}$ cells release exosomes containing microRNA that are capable of directly inducing anti-inflammatory responses in the recipient cells (Anderson et al. 2016). Exosomes have a crucial role in viral transport and also serve as a delivery cargo for therapeutics to induce antiviral immunity. Virus fuses with intraluminal vesicles and enters late endosomes to unload their genomes in the cytoplasm (Anderson et al. 2016; Crenshaw et al. 2018). MVs and exosomes can help spread the virus and its components from infected macrophages to other cells (Kadiu et al. 2012).

\section{Isolation, Purification and Production}

EVs are readily isolated from cell cultures and biological fluids using a broad range of techniques (Gardiner et al. 2016; Gao et al. 2020a). These techniques include differential speed ultracentrifugation, polymer-based precipitation, immune-affinity capture, size-exclusion chromatography, microfluidics, and ultrafiltration (Greening et al. 2015; Lobb et al. 2015; Zeringer et al. 2015). EVs act as conduits for the transfer of biologically-active molecules between cells. The processes are similar to how viral particles transfer their genetic material between cells during microbial infection and most notable for viruses (Crenshaw et al. 2018; Nasiri Kenari et al. 2020). To such ends, there are multiple ways to isolate, purify, and concentrate viruses that parallel pathways seen for EVs (Greening et al. 2015; Börger et al. 2019). In the case of viral infection, isolation of pure EVs requires separation of ingested virus or viral particles (McNamara et al. 2018). Separation of EVs and viruses based on physical parameters alone is difficult due to the similar small sizes $(<$ $200 \mathrm{~nm}$ ) and densities (EVs: 1.13-1.18 g/L; most retroviruses:
1.16-1.18 g/L) (Cantin et al. 2008; McNamara et al. 2019). Viruses overlapping with the densities of EVs (such as human immunodeficiency virus 1 (HIV-1) and co-sediment under the same high centrifugal force $(100,000 \mathrm{x} \mathrm{g})$ that isolate EVs (McNamara et al. 2018). Methods such as crossflow filtration (also known as tangential flow filtration, TFF) are capable of processing large fluid volumes used to concentrate both EVs and viruses while strictly adhering to current good manufacturing practices (cGMP) (Börger et al. 2019).

Conventional methodologies for maintenance and expansion of cells rely on a two-dimensional culture carried out in flasks with low yield of EVs (McKee and Chaudhry, 2017; Chance et al. 2019). However, recent studies with MSCs showed that use of three-dimensional cultures such as used with fixed-bed and in-stirred tank bioreactors, or continuous production in perfusion reactors could enhance scale ups for EVs production (Whitford et al. 2015; Colao et al. 2018). Cultivation of human umbilical cord derived-MSCs microcarrier-based three-dimensional cultures resulted in twenty-fold greater yield of EVs than planar, twodimensional cultures, with improved activity (Haraszti et al. 2018; Thippabhotla et al. 2019). This has been used successful for siRNA delivery to the neurons (Haraszti et al. 2018). EVs isolated from stem cell culture by ultrafiltration followed by size-exclusion chromatography result in higher EVs yield and preserve the biophysical and functional properties (Nordin et al. 2015; Benedikter et al. 2017). Size exclusion chromatography is compared and proven to be superior to the most popular ultracentrifugation methods in terms of retaining EVs' biological properties (Mol et al. 2017; Monguio-Tortajada et al. 2019). There is no gold standard accepted for EVs isolation and methods have been left at the discretion of researchers to define relevant method for their individual study (Greening et al. 2015; Lobb et al. 2015). Reports suggest that EVs isolation and purification method does not only influence yield, purity, and size distribution, but also nucleic acid cargo (Tang et al. 2017; Stranska et al. 2018). Another example is a recent study that compared traditional ultracentrifugation methods to commercial isolation kits (ExoQuick and Total Exosome Isolation Reagent) to obtain EVs from culture medium and sera (Rekker et al. 2014; Tang et al. 2017; Stranska et al. 2018). Finding optimal EVs extraction efficiency with limited protein contamination as well as best RNA yields remains a dominant goal in any procedure. (Tang et al. 2017). Distinct miRNA profiles are obtained based on the types of isolation method when confirmed by RNA sequencing (Rekker et al. 2014; Ding et al. 2018; Stranska et al. 2018). Such differences in cargo composition supports the need for a comprehensive evaluation and development of effective, high-throughput methods for consistent yet higher yield of pure EVs with desired biological cargos (Helwa et al. 2017). Such means when found would serve to accelerate best EVbased diagnostics and therapeutics (Bari et al. 2020). 
Regardless of which method used to isolate and concentrate EVs each method requires standardization in order to optimize reproducibility, purity, and maintenance of EVs' functional properties (Gardiner et al. 2016; Khalaj et al. 2020).

\section{Sources of EVs}

Mammalian: Mammalian endothelial cells, immunocytes, epithelial cells, MSCs, and cancers all release EVs in different biological fluids (Akers et al. 2013; Abels and Breakefield, 2016). EVs contain bioactive entities which are crucial in cellto-cell communication and play a key role in physiological and pathological functions (Soares et al. 2015). Moreover, mammalian EVs are also involved in regulating immune responses, angiogenesis, coagulation, and miRNA transfer (Yanez-Mo et al. 2015). Mammalian EVs-based delivery systems provide several advantages, such as excellent biocompatibility and stability in the blood, offer protection for proteins, chemotherapeutics, nucleic acids, and structural similarity to other immune cells and viruses, all of which facilitate cell membrane crossing and targeted delivery (Vader et al. 2016). EVs are secreted by mammalian cells during inflammation. EVs generated by normal cells can also produce inflammatory mediators, which activate the immune responses (Yanez-Mo et al. 2015). T cells and monocytes secrete vesicles decorated with FasL that modulate apoptosis of other cells (Russell, 1995). The major limitations of mammalian EVs are (i) their complex structure which makes duplication difficult; and (ii) a limited understanding of their mechanisms of action (S et al. 2013; Tsiapalis and O'Driscoll, 2020).

Bacterial: Gram-negative bacterial EVs were observed in electron microscopy (Brown et al. 2015). Commonly known as outer membrane vesicles (OMVs), bacterial EVs are secreted from gram-negative bacteria with the size range of 20 $200 \mathrm{~nm}$. Later studies confirmed the release of EVs (20$100 \mathrm{~nm}$ ) from gram-positive bacteria as well (Kim et al. 2015a). Gram-negative bacteria OMVs contain several virulence factors and immune-stimulating biomolecules. The major immune-stimulating biomolecules are lipopolysaccharide (LPS) and their outer membrane proteins, which attracted the attention of researchers as acellular and adjuvant free vaccines (Jan, 2017). Bacterial EVs are potent candidates for bacteriarelated immune responses. For example, exosomes produced via infection of macrophages with Mycobacterium bovis BCG were shown to promote both CD4 and CD8 T cells in the presence of dendritic cells (DCs). They were also shown to promote the memory of CD4 and CD8 T cells upon intranasal immunization (Giri and Schorey, 2008). Hence, the researchers investigated their use as an acellular vaccine member, which is like a mediator of antigen-specific immune responses (McConnell et al. 2011). Recently, several bacterial
EVs, such as Neisseria meningitidis, Salmonella enterica (Serovar Typhimurium), Acinetobacter baumannii, and Helicobacter pylori, all showed efficacy as a vaccine (Huang et al. 2016). Interestingly, several countries are using OMVs as a vaccine for meningococcal disease in children. BEXSERO is a bacterial EVs-based approved marketed vaccine used in children in several countries (Gorringe and Pajon, 2012). Recently Kim et al. developed the bacterial protoplastderived nanovesicles (PDNVs) as an adjuvant-free vaccine delivery system (Kim et al. 2015b). PDNVs showed efficient antigen-specific humoral and cellular immune responses with great productivity and safety profile. Results further showed efficient protection of loaded bacterial antigens from bacterial sepsis in mice (Kim et al. 2015b). Bacterial EVs play a key role in the activation of target cells through indirect induction, but show several pathophysiological activities once moved into the host cell (Rodrigues et al. 2018; Malkin and Bratman, 2020). The major limitations of bacterial EVs are that (i) their toxic effects due to virulent factors on the surface, (ii) the mechanism is not well established yet, and (iii) mass production is difficult (Rodrigues et al. 2018).

MVs are pathogenic or protective during bacterial infections (Bhatnagar et al. 2007; Malkin and Bratman, 2020). The pathologic roles include, for example, the ability of platelet MVs to increase immunocyte binding to the endothelium (Barry et al. 1998). MVs in sepsis carries tissue factor (TF) and contribute to the procoagulant state (Nieuwland et al. 2000). Correlation between MV-associated TF activity and the circulating levels of bacterial lipopolyscchardie (LPS) in meningococcal septic shock are noted (Hellum et al. 2014). Upregulated cellspecific surface antigens on endothelial MVs were detected in patients with disseminated intravascular coagulation in the context of sepsis (Matsumoto et al. 2015). In human endotoxemia (induced by LPS, induces a lethal disease characterized by high blood levels of pro-inflammatory cytokines and shock), MVs can promote coagulation in a factor XI-dependent manner (Mooberry et al. 2016). Exosomes derived from M. tuberculosis $\mathrm{H} 37 \mathrm{Rv}$-infected, but not from uninfected, macrophages, inhibited interferon gamma (IFN- $\gamma$ ) responsive genes, notably the major histocompatibility complex class II (MHC-II) transactivator. This resulted in a down-modulation of MHC-II and CD64 expressions on bone marrow-derived macrophages, suppressing the antimicrobial responses provided by $\mathrm{T}$ cells (Singh et al. 2011).

Conversely, other reports documented the protective roles of MVs. The septic patients' MVs restored LPS-induced vascular hyporeactivity and increased IL-10 in a tissueengineered blood vessel model (Mostefai et al. 2013). In vitro, LPS-elicited monocytic MVs that can improve the integrity of microvascular endothelial cells, as evidenced by a reduced permeability and an increased trans-endothelial electrical resistance of the monolayer (Sarich, 1972). Levels of 
MVs and MV-cell conjugates were found in septic patients to suggest a favorable outcome (Soriano et al. 2005). Exosomes released from mycobacterium-infected macrophages contain pathogen-associated molecular patterns (PAMPs) and elicited proinflammatory responses, such as tumor necrosis factor (TNF) and IL-12 production, as well as neutrophil and macrophage recruitment (Bhatnagar et al. 2007). In addition to PAMPs, exosomes and MVs released by macrophages infected with mycobacteria contain MHC-II molecules allowed them to participate in antigen presentation for M. tuberculosis antigen (Ag) 85B(241-256)-I-Ab complexes (Ramachandra et al. 2010). This mechanism of antigen presentation by EVs is important in the generation of antimicrobial $\mathrm{T}$ cell responses (Singh et al. 2011).

Platelet-derived: A platelet-derived extracellular vesicle (PEV) platform was developed which comprised nano-sized membrane vesicles $(100-150 \mathrm{~nm})$ derived from platelets (Wang et al. 2017; Hu et al. 2018). Due to excellent inflammatory targeting ability, platelets use (size $1-3 \mu \mathrm{m}$ ) as carriers may exacerbate the inflammation and progression of pneumonia. However, PEVs derived from platelets which lack some cytosolic proteins such as actin but express targeting molecules on the surface including CD41, do not aggravate the inflammation and progression of pneumonia but still possess the inflammatory targeting ability (Ma et al. 2020). The targeting ability of PEVs to the inflammatory lungs was verified in vivo by intravenously injecting DiIC18(5); 1,1'dioctadecyl-3,3,3',3'- tetramethylindodicarbocyanine, 4chlorobenzenesulfonate salt (DiD)-labelled PEVs into acute lung injury (ALI) mice where PEVs bind with inflammatory M1-type macrophages and other inflammation-associated cells evidenced by near-infrared (NIR) fluorescence imaging. Moreover, PEVs did not accumulate in healthy lung tissue, signifying an excellent inflammation-targeting ability of PEVs (Guo et al. 2017). Such PEV ability to target inflammatory lung tissue can be employed to neutralize SARS-CoV-2 for the treatment of COVID-19 (Fig. 2).

EVs can also serve as a carrier for the drug molecules and the nucleic acids (DNA, mRNA) for the targeted delivery and to lower toxicities associated with the native drug (Fig. 2) (de Jong et al. 2019). Based on the targeting ability of PEVs nanoplatform, the performance of PEVs as drug nanocarriers was assessed by loading PEVs with an anti-inflammatory molecule, TPCA-1 (TPCA-1-PEVs), to calm cytokine storm syndrome from monocytes. An intravenous injection of TPCA-1-PEVs ( $1 \mathrm{mg} / \mathrm{kg}$ of TPCA-1) significantly lowered levels of IL- 6 and TNF- $\alpha$ in the ALI mice $20 \mathrm{hr}$ post injection. Additionally, the inflammatory cell infiltration in TPCA-1PEVs treated mice was substantially lowered compared to the untreated ALI group and free drug treatment group. Therefore, TPCA-1 delivery by biomimetic PEVs-based nanocarriers has the potential to treat patients with cytokine storm syndrome, as well as those severe cases of COVID-19 (Ma et al. 2020). Convalescent plasma treatment has been successfully used for the management of COVID-19 which consists neutralizing antibodies, growth factors and EVs (Rojas et al. 2020). Although plasma derived antibody treatments have been approved for the treatment of COVID-19 (BioPharma-Reporter, 2020; Xi, 2020), the studies with plasma EVs are lacking. Protective effects of convalescent plasma in COVID-19 might be partially attributed to plasma EVs which exhibit plethora of immunomodulating molecules (Fig. 2) (Tao et al. 2017; Shi et al. 2020).

Immune Cells: Several studies have shown the importance of APCs-derived EVs in stimulating the immune system. DCs releasing exosomes are assumed to be an important factor in peripheral immune tolerance. Studies have shown that exosomes derived from DCs, which express MHC-I and CD86, have potential immune-stimulatory activities in vivo (Li et al. 2006). DCs having increased intercellular adhesion molecules (ICAM1) help binding of APCs to the vesicles and enhance APC/T cell interactions (Cintolo et al. 2012; Montecalvo et al. 2012). Integrin lymphocyte functionassociated antigen (LFA1) undergoes conformational changes by $\mathrm{T}$ cell activation, which increases the $\mathrm{T}$ cells' affinity for ICAM1 on DC-derived exosomes (Zepeda-Cervantes et al. 2020). Non-professional APCs have the capability to activate naïve $\mathrm{T}$ cells from $\mathrm{DC}$-derived exosomes. Once EVs are internalized by DCs, the antigens derived from degraded exosomes contain MHC-peptide complexes which are used to stimulate $\mathrm{T}$ cells indirectly (Zhou et al. 2012). B cells producing EVs carry MHC-II, co-stimulatory, and adhesion molecules, that induce T cell clones (Cintolo et al. 2012; Zhou et al. 2012). EVs produced by APCs carry MHC-I and MHCII molecules on their vesicle surface and can stimulate CD4 and CD8 T cells (Lindenbergh and Stoorvogel, 2018). EVs can also stimulate $\mathrm{B}$ and $\mathrm{T}$ cell interactions in an antigenspecific manner, and thus help in maintaining antigenspecific memory T cells (Robbins and Morelli, 2014; Harrell et al. 2019). Overall, EVs significantly contribute to the adaptive and innate immune responses as well as associated immune functions (Robbins and Morelli, 2014).

Along with similar mechanisms that DCs display, mast cells (MCs) also display peptide-loaded MHC-II and costimulatory molecules ( $\mathrm{Li}$ et al. 2016). In vitro studies have shown that mast cells induce antigen-specific $\mathrm{T}$ cell response by forming a "traditional" immunologic synapse with it (Carroll-Portillo et al. 2012). Mast cells are known to be activated in several viral pathways. Exosomes released from mast cells help to activate T cells (Tsai et al. 2011; Marshall et al. 2019). In vitro, exosomes derived from IL-4 treated mice induce lymphocyte proliferation and production of IL-2 and IFN- $\gamma$ (Tsai et al. 2011). In vivo study also showed proliferation of lymphocytes and cytokine production when mice 


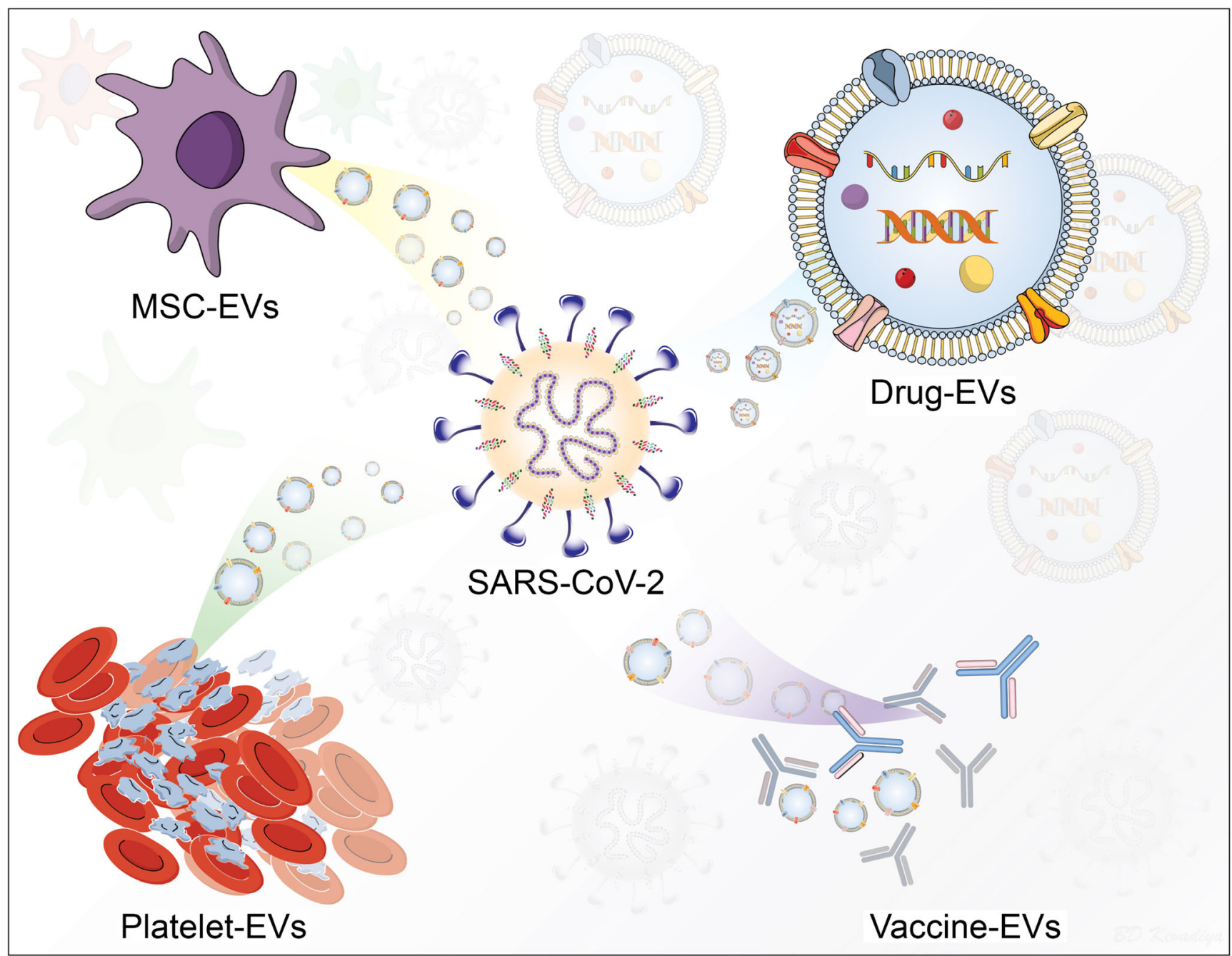

Fig. 2 Approaches to use EVs for the treatment of COVID-19. MSCs induce immunoprotective and regenerative effects through EVs secretion. Therefore, EVs isolated from different source MSCs can directly affect the SARS-CoV-2. EVs also serve as natural carrier allow encapsulation of nucleic acids or small drug molecules for targeted delivery. Platelets were believed to induce exclusively proinflammatory responses.

treated with mast cell-derived exosomes containing costimulatory molecules (Tsai et al. 2011). Exosomes derived from the bone marrow mast cells (BMMC) showed proliferation and differentiation of naïve $\mathrm{T}$ cells into $\mathrm{Th} 2$ cells in a contact-dependent manner by ligation of OX40/OX40 L between the CD4 $\mathrm{T}$ cells and the BMMC exosomes ( $\mathrm{Li}$ et al. 2016). APC-derived exosomes also have immunosuppressive activities, which are useful in therapeutic approaches and transplantations (Le Blanc and Ringden, 2007; Harrell et al. 2019).

Laboratory studies have shown that EVs induced CD8 T cells to produce IFN- $\gamma$ when pulsed with viral peptides (Robbins and Morelli, 2014). EVs derived from infected cells get captured by APCs immediately and are followed by indirect dissemination of antigens to initiate an immune response in a synergistic manner (Thery et al. 2009; Schorey et al.
However, recent studies identified that EVs secreted from platelets exclusively exhibit anti-inflammatory and immunomodulating effects with ability to target inflammatory site. Convalescent plasma induced protective effects are attributed to neutralizing antibodies, growth factors and partially through their EVs. All these approaches can be used to target SARS-CoV-2 inflammatory sites and contain COVID-19

2015). Cytomegalovirus (CMV) infected human endothelial cells have been shown to release exosomal vesicles containing CMV gB surface fusion protein that stimulate memory B cells in the presence of APCs (Plazolles et al. 2011). Similarly, T cells were found to produce endosomes that segregate the HIV Gag protein into plasma membrane-derived EVs (Booth et al. 2006). Exosomes isolated from sera of porcine respiratory and reproductive syndrome virus (PRRSV) infected pigs were shown to contain antigenic viral proteins that reacted with immune sera from pigs that had been previously exposed to PRRSV in a dose-dependent manner (Montaner-Tarbes et al. 2016). Exosomes carry viral mRNAs that can be recognized as PAMPs by PPRs in target cells to stimulate a strong innate immune response (Zomer et al. 2010; Alvarez-Erviti et al. 2011). For example, EVs carrying viral RNA from human hepatitis $\mathrm{C}$ virus infected cells were shown to stimulate 
plasmacytoid dendritic cells, pDCs (Dreux et al. 2012). EVs exhibit dual functional roles in immunological responses. Several studies on the dual role of EVs in the spread and management of viral infection, especially in the context of Epstein-Barr virus (EBV), HIV, Kaposi's sarcoma associated herpesvirus, hepatitis $B$ virus, and hepatitis $C$ virus, have been well-documented (Urbanelli et al. 2019). EVs may negatively regulate the spread of viral infection by inducing immune responses against viruses, while EVs may also assist viral dissemination by dampening antiviral immune responses (Elrashdy et al. 2020b). EVs may act as "eliminating-cargo" of unwanted molecules, and thereby having antigenic or pathogenic potential, such as an antiviral response and downregulation of immunological reactions (Petrik, 2016; Fujita et al. 2018). However, EVs may also act as a "signaling-tool" that elicits an immune response by delivering a variety of materials having antigenic potential, viz. soluble proteins, transmembrane peptides, bi-functional lipids (phosphatidylglycerol, lyso-phosphatidylcholine), and nucleic acids (miRNAs), and hence spreading the infection (S et al. 2013; Schwab et al. 2015; Schorey and Harding, 2016; Kouwaki et al. 2017).

EVs and some infectious agents, such as viruses, share common properties, primarily size, structure, generation, and cellular uptake. Endosomal sorting complexes required for transport (ESCRT) machinery are involved in both EVs and virus generation (Votteler and Sundquist, 2013). Moreover, viruses can use $\mathrm{EV}$ endocytic routes to enter the uninfected cells and hijack the cellular secretory pathway to exit the infected cells (Urbanelli et al. 2019; Badierah et al. 2020). The viral infection affects the exosome loading mechanisms in infected cells because the protein and nucleic acid content of EVs are changed after infection (Raab-Traub and Dittmer, 2017). Thus, these altered EVs may also modulate the immune response of the host with respect to EVs released from the uninfected cells (de Jong et al. 2019; Kumar et al. 2020). Many studies have provided evidence about the antiviral effects of EVs released from immune cells, such as macrophages, and other cells infected with viruses (Petrik, 2016; McNamara et al. 2019). Resident immune cells of the lungalveolar macrophages (AMs) and alveolar epithelial cells (AECs) that comprise the alveolar surface have shown an indispensable role in host defense at the early stages of influenza infection. Resident AMs have shown antiviral defense against influenza infection of the lung as a consequence of AM-derived EVs (AM-EVs) uptake within endosomes (Schneider et al. 2020b). Influenza is transmitted to the proximal airways of infected person(s), wherein the virus infects and replicates within EVs. The ability of AMs to protect AECs from influenza infection are mediated by paracrine communication between AM-EVs and recipient AECs (Hassanpour et al. 2020; Schneider et al. 2020b). EVs were proven to play an important role through neutralizing extracellular antigens, engaging surface receptors on target cells, and transferring biologically active cargos (lipids, nucleic acids, proteins) that can exert intracellular actions in recipient cells (Lima et al. 2009; Atay et al. 2011; Pitt et al. 2016; Robbins et al. 2016). These features positioned AM-EVs as nimble vectors for an innate immune response to the viral infections within the dynamic lung environment (Schneider et al. 2020a; Schneider et al. 2020b). More evidence of the antiviral effect of EVs was that EVs isolated from IFNstimulated macrophages could secrete various cytokines shortly after stimulation with type I and II IFN, which orchestrated a fast but short-lasting antiviral state against hepatitis $\mathrm{C}$ virus (Cai et al. 2018). This rapid innate immune effect was followed by the production of EVs which induced a late, but long-lasting inhibitory effect on hepatitis $\mathrm{C}$ virus replication (Cai et al. 2018). Additionally, the exposure of macrophages to polyunsaturated fatty acids, which are important regulators of immune responses, dampened EVs-mediated antiviral immune responses against hepatitis $\mathrm{C}$ virus (Cai et al. 2018). Viral miRNAs, such as miR-H28 and miR-H29, can be encapsulated into EVs and subsequently isolated from the herpes simplex virus type 1 (HSV-1) infected cells (HEK293T, HEp2, and Vero cells) (Han et al. 2016b). The abnormal expression of these miRNAs in the infected cells resulted in a decreased expression of viral gene products and inhibition of infection spread from infected cells to healthy cells (Han et al. 2016b). HSV-1 infected cells were shown to release EVs, so that they are enriched with a stimulator of interferon genes (STING), a protein that inhibits the viral spread and augmented host cell survival (Kalamvoki et al. 2014). Other studies demonstrated the role of EVs in the dissemination of viral infections (Ali et al. 2010; Raymond et al. 2011). EVs, including exosomes, may incorporate viral proteins and/or fragments of viral RNAs to carry them from infected cells to target uninfected cells to spread the viral infection (Thery et al. 2009; Raab-Traub and Dittmer, 2017; Urbanelli et al. 2019). EVs also transfer HIV proteins to target cells, such as Jurkat CD4 + T cells, THP-1, and U-937 monocytic leukaemia cell lines, and thus contribute to infection spread by making the target cells susceptible to HIV (Ali et al. 2010; Raymond et al. 2011). CMV-infected cells were also shown to release EVs that suppress antiviral responses of the host, which subsequently increased viral infectivity. CMV infection increased the release of EVs containing lectin and DC-specific intercellular adhesion molecule-3 grabbing non-integrin proteins (DC-SIGN), both of which are required for virus-cell update (Plazolles et al. 2011). These vesicles have the potential to promote myeloid DCs infection, indicating a fall in antiviral responses (Plazolles et al. 2011).

EVs can transfer ACE2 to recipient cells that includes endothelial progenitor cells and as such are susceptible to viral docking (Hassanpour et al. 2020; Wang et al. 2020a). This supports a role for exosomes in SARS-CoV-2 internalization and infection (Hassanpour et al. 2020; Wang et al. 2020a). 
The primary site of SARS-CoV-2 infection is in the lung. The lung is highly vascular enabling viral spread to tissues that include the kidney and intestine as the virus evidenced in urine and stool (Ling et al. 2020; Wang et al. 2020b). SARS-CoV-2 utilizes EV-transport for replication and intra-host spreading in systemic virus dissemination (Elrashdy et al. 2020b; Elrashdy et al. 2020a). This "Trojan horse" strategy to release the SARS-CoV-2-loaded EVs represent the appearance of viral RNA in COVID-19 patient fluids (Elrashdy et al. 2020b). Infected patients show viral RNA up to 10 to 27 days after discharge (Korber et al. 2020; Ye et al. 2020). The median duration of virus in body fluids is 20 days but can be observed up to 37 days (Zhou et al. 2020). In limited numbers of patients, SARS-CoV-2 RNA remains detectable for up to 53 days with a maximum of 83 days ( $\mathrm{Li}$ et al. 2020b; Ye et al. 2020; Yuan et al. 2020). The presence of the potential for some hospital discharged COVID-19 patients to develop reinfection or reactivation indicates the presence that effective antiviral immune response to SARS-CoV-2 may not always occur (Gao et al. 2020b). COVID-19 reinfection or reactivation can be explained by (i) ineffective, (ii) strain-specific, or (iii) short-lived anti-SARS-CoV-2 immune responses. Furthermore, SARS-CoV-2 infections could develop "escape mutants" (Chaturvedi et al. 2020). This is reflected by the fact that SARS-CoV-2 can be present within vacuoles or doublemembrane vesicles in host cells. This was proven by the postmortem histopathological analysis of tissues of COVID-19 patients by light and electron microscopy (Farkash et al. 2020; Su et al. 2020). In some SARS-CoV-2 autopsies, cytoplasmic viral particles can be detected in pneumocytes and within the nervous system and intestinal cells and tissues (Deshmukh et al. 2020). Most of these viral particles are found within membrane-bound vesicles. Viral particles have also been observed in macrophages in lung tissues. Furthermore, the presence of inclusion bodies within the infected cells has been reported in several studies, with the viral origin of such inclusion bodies being confirmed by immunogold labeling (Gu and Korteweg, 2007; Zeng et al. 2020). These findings indicated that SARS-CoV-2-containing EVs are manufactured and assembled intracellularly, and such possible exosomal cellular transport support systemic SARS-CoV2 dissemination and COVID-19 reactivation.

MSCs: Despite extensive efforts worldwide in the search for therapeutic strategies to treat COVID-19, no investigated therapeutics or biologics have been found strongly effective (Florindo et al. 2020). Stem cell-based therapeutic intervention and, in recent times, their secreted EVs, are evolving as new treatment modalities, which could mitigate inflammation but also regenerate the lung damage caused by cytokine storm syndrome that COVID19 induces (Mehta et al. 2020). Stem cells, particularly MSCs, exert potent and broad immunomodulatory, anti-inflammatory, and regenerative effects mainly via utilizing their EVs. Therefore,
MSC-EVs could be useful when used alone or in combination with other therapeutics for COVID-19 patients (Chrzanowski et al. 2020). MSCs are heterogeneous populations of cells comprising stem cells, stromal cells, progenitor cells, and fibroblasts (Dominici et al. 2006; Galderisi and Giordano, 2014). These cells are obtained from various tissues including placenta, bone marrow, cord blood, adipose tissue, Wharton jelly, dental pulp, and umbilical cord (Muraca et al. 2020; O’Driscoll, 2020). MSCs are of two types, namely MSC1 (pro-inflammatory) and MSC2 (anti-inflammatory). Specific-antigens that act as ligands are responsible for a unique bidirectional polarization where toll-like receptors play an important role (Yi and Song, 2012). MSCs secrete epidermal growth factor (EGF), angiopoietin 1 (ANGPT1), keratinocyte growth factor (KGF), hepatocyte growth factor (HGF), and vascular endothelial growth factor (VEGF), all have been identified to promote regeneration and protection of alveolar epithelial cells (Zhen et al. 2008; Bernard et al. 2018). In addition, MSCs secrete cytokines (IL-1RA, IL-10, and TGF- $\beta$ ), nitric oxide, and indoleamine 2,3 dioxygenase (IDO), which regulate immune cells toward an anti-inflammatory phenotype (Matthay et al. 2010; Pedrazza et al. 2017). Besides, MSCs could enhance bacterial clearance by stimulating the phagocytosis activity of macrophages through the secretion of antimicrobial factors, like peptide LL-37 and lipocalin-2 (Krasnodembskaya et al. 2010; Mei et al. 2010; Gupta et al. 2012). MSCs are known to exhibit most of their pharmacological benefits through secreted EVs which carry all the essential bioactive factors (Muraca et al. 2020; O’Driscoll, 2020).

MSC-EVs have demonstrated a plethora of therapeutic benefits in various preclinical and clinical studies, including repair of damaged lung tissues, stabilization of fluid leakage in lung epithelium, sustenance of lung permeability, and management of lung edema (Bhattacharya and Matthay, 2013; Brown et al. 2019). Interestingly, MSC-EVs, in their naturally secreted form possess anti-inflammatory and immunomodulatory effects even during COVID-19 infection (Harrell et al. 2019; Sengupta et al. 2020). Preclinical studies showed the therapeutic efficacy of MSC-EVs in various disease models such as bronchopulmonary dysplasia, asthma, lung fibrosis, and chronic obstructive pulmonary disease (Cruz et al. 2015; Srour and Thebaud, 2015; Ahn et al. 2018; Fujita et al. 2018; Mohammadipoor et al. 2018; Willis et al. 2018). MSC treatment recovered mouse models from Japanese encephalitis virus (JEV) infection along with the reduction in neuronal damage, blood-brain barrier (BBB) destruction, inflammatory response, and viral load (Bian et al. 2017). Recently, MSC transplantation reduced mortality in patients with H7N9 virus-induced ARDS without any side effects (Chen et al. 2020). Administration of MSC-EVs in a pig model, after the influenza challenge, showed a significant decline in viral shedding and replication, in addition to the decline in the release of pro-inflammatory cytokines in the lungs (Khatri et al. 2018). It shows that MSC-EVs can act as anti-influenza and antiinflammatory agents against the viral infection, and hence they 
may be used as cell-free therapy in humans (Sengupta et al. 2020; Tsiapalis and O'Driscoll 2020). Currently, the first clinical trial on the safety and aerosol tolerance of EVs isolated from adipose tissue-derived MSCs was launched in March 2020 at Ruijin Hospital in Shanghai (China) (NCT04313647). Such studies make MSC-EVs a strong candidate to treat SARS-CoV-2 associated ARDS.

MSC-EVs' capability to carry nucleic acids, miRNAs, IncRNA, and circRNA (Yu et al. 2016; Kim et al. 2017) and the cell's abilities to present antigens have sparked interest for COVID-19 efforts to develop effective long-term vaccines and therapeutics (Borger et al. 2020; Sengupta et al. 2020). Additionally, MSC-EVs can be delivered intranasally, which is essential for treating COVID-19 lung infection. This can afford early onset of action and better therapeutic efficacy (Leng et al. 2020). Inability of MSC-EVs to self-replicate in absentia of genetic information also eliminates the risk of cellular overload and tumorigenicity (Chrzanowski et al. 2020; O'Driscoll, 2020). MSC-EVs are preferred over MSCs due to their stability and long-term storage capabilities (Cha et al. 2018). This makes the therapy accessible broadly without the requirement of on-site cell-based manufacturing facilities (Chrzanowski et al. 2020). However, significant efforts are now required to develop reliable potency tests for MSC-EVs before they can be considered for COVID-19related cytokine storm syndrome (Fig. 2).

\section{Therapeutic Potential}

The growing amount of research gives credence towards the importance of EVs in tissue and cell homeostasis and delivery (S et al. 2013; Robbins and Morelli, 2014). EVs' cargoes reflect the content of the parent cells and EVs have the potential to serve as a surrogate to cells in biological fluids. This could reveal prognostic information for a range of diseases (Manna et al. 2018; Jayaseelan, 2020). Moreover, it could serve as clinical biomarkers (Lin et al. 2015; Nedaeinia et al. 2017). Thus, EVs have use in vaccine as natural antigen carriers and to target distal organs. EVs can be used either in its naturally secreted or engineered form for targeted therapy (Gilligan and Dwyer, 2017; Cooper et al. 2020; Ni et al. 2020).

Exosomal vaccines were studied in the preclinical studies since the early 2000s and for their neutralizing antibody carriage capabilities (Abels and Breakefield 2016; Petrik 2016). Exosome-based vaccine platform was developed wherein an array of viral antigens was fused with the $\mathrm{Nef}^{\text {mut }}$ protein at the C-terminus of exosome. When injected into the mice, such engineered exosomes elicited detectable antigen-specific cytotoxic T cell responses (Anticoli et al. 2018). In related works with the Medical Research Council Cell strain 5 cells EVs were found to protect against rabies viral infections (Wang et al. 2019). This was realized by the intercellular delivery of exosomal miR-423-5p (Wang et al. 2019). In support of EV and vaccine developments, an intramuscular injection of a DNA vector expressing E7 oncoprotein of human papillomavirus fused to the $\mathrm{C}$-terminus of exosome showed high expression of target protein and elicited strong antigen-specific cytotoxic $\mathrm{T}$ cell responses (CTL) compared to its wild type variant (Anticoli et al. 2018). Such approach can be used to incorporate immunogenic antigens into EVs and from a range of pathogens. These pathogens include Ebola virus VP24 and VP40, influenza virus, Crimean-Congo hemorrhagic fever virus, West Nile virus NS3, and hepatitis C virus (Anticoli et al. 2018).

While EVs serve as excellent carriers for viral antigens and present them in their native state for an effective immune response, they can also carry host-derived antiviral compounds and immune enhancers (Petrik, 2016; Rodrigues et al. 2018). For example, EVs released by HIV-1-infected cells can transport APOBEC3G (A3G), a host antiviral cytidine deaminase protein. A3G-loaden exosomes have been shown to confer antiviral phenotype to the target cells (Khatua et al. 2009). EBV-infected Raji cells can release exosomes containing deoxyuridine triphosphatase (dUTPase) that induce NF-kB activation as well as cytokine secretion as present in both primary DCs and peripheral blood mononuclear cells (Ariza et al. 2013). dUTPase can be exploited as an adjuvant for exosomal vaccines (Ariza et al. 2013). Furthermore, exosomes produced from lymphoblastoid B cell line (LCL1) that express EBV structural protein gp350, can selectively target $B$ cells to induce robust antiviral immune responses (Vallhov et al. 2011). Thus, adding a gp350 component can generate B cell targeted vaccines that can potentially induce a long-lasting $\mathrm{T}$ cell immunity (Vallhov et al. 2011). A chimeric SARS-CoV S protein is generated by replacing the transmembrane and cytoplasmic domains of the $\mathrm{S}$ protein with vesicular stomatitis virus $\mathrm{G}$ protein. HEK293T cells can produce exosomes bearing chimeric SARS-CoV S protein (Kuate et al. 2007). Two injections of exosomal S protein vaccine induced neutralizing antibodies comparable to the adeno-associated virus (AVV) vaccine expressing chimeric $S$ protein without the aid of adjuvant. The immunogenic responses of exosomal $\mathrm{S}$ vaccine were boosted after the subsequent injection of AAV S vaccine (Kuate et al. 2007). Based on this knowledge, exosomes from SARS-CoV-2 infected cells may induce similar immune responses (Elrashdy et al. 2020b; Pocsfalvi et al. 2020).

Several clinical trials have assessed the efficacy of umbilical cord-derived MSCs in COVID-19 patients. All are free from ethical constrains and as such enable broad application (Alzahrani et al. 2020). In all the clinical studies, MSCs treatment improved the COVID-19 patient conditions compared to the standard antiretroviral therapy (Leng et al. 2020; Liang et al. 2020; Shu et al. 2020). In these studies, MSCs were 
injected through the intravenous route that may result in aggregation or clumping in the microvasculature and the umbilical cord source is associated with the risk of oncogenicity and mutagenicity due to their ability to differentiate in their target tissue (Han et al. 2016a; Coppin et al. 2019). MSCs-EV and native cells, however, are known to induce similar responses and therefore, MSC-EVs are considered safe and a best alternative compared to native MSCs (Tsiapalis and O'Driscoll, 2020). Currently, more than sixty clinical trials are ongoing to study the effects of MSCs and EVs in the COVID-19 patients (EVs studies are summarized in Table 1). A Phase 1 clinical trial to assess the safety and efficacy of the inhaled exosomes derived from the allogenic adipose MSCs for the treatment of COVID-19 pneumonia is completed. Severely ill hospitalized COVID-19 patients received a dose of $2 \times 10^{8}$ exosomes for five consecutive days along with the conventional antiretroviral therapy. However, the study results are not published yet (NCT04276987). The same researchers' group is assessing safety and tolerance of the inhaled exosomes derived from the allogenic adipose MSCs in Phase 1 clinical trial using up to eight times higher dose of the exosomes, at $16 \times 10^{8}$, in the healthy volunteers (NCT04313647). Direct Biologics has developed ExoFlo ${ }^{\mathrm{TM}}$, an exosome therapy derived from the allogenic bone marrow MSCs for the treatment of severely ill COVID-19 patients. In Phase 1 study, with 24 hospitalized COVID-19 patients, a single dose administration of ExoFlo ${ }^{\mathrm{TM}}$ was found safe and well tolerated. Fourteen days after ExoFlo ${ }^{\mathrm{TM}}$ treatment, patients experienced improved oxygenation, downregulated ARDS and restored immune cells (Sengupta et al. 2020). After these encouraging results, a multicentric Phase 2 clinical trial (EXIT-COVID-19) is initiated to enroll 60 moderate-to-severe COVID-19 patients with ARDS to assess therapeutic efficacy of ExoFlo ${ }^{\mathrm{TM}}$ (NCT04493242). Recently, Direct Biologicals received extended access for ExoFlo ${ }^{\mathrm{TM}}$ from the U.S.A. FDA for the treatment of COVID-19 associated ADRS for the EXITCOVID-19 clinical trial (PR Newswire, 2020). Several other clinical trials are ongoing in China with EVs derived from the MSCs to treat pneumonia and recover lung damage caused by SARS-CoV-2 with results awaiting completion (ChiCTR2000030261, ChiCTR2000030484).

\section{Clinical Challenges}

EVs can be developed as a diagnostic, therapeutic or theranostic agents by loading variety of agents into EVs and by surface engineering using a broad number of techniques including click chemistry, hydrophobic insertions and displays. Although, such technologies offer advantages of EV stability, biocompatibility and modest immunogenicity over toxic nanoparticles, producing EVs in sufficient large quantity with specificity and reproducibility of drug transport remains an impediment for human use (Man et al. 2020; Meng et al. 2020).

Moreover, there are several technological and regulatory issues that pose uncertainty about EVs therapeutics. EVs are heterogenous populations of vesicles with heterogenous cargo components (consisting of proteins, lipids and RNAs) (Yanez-Mo et al. 2015; Kawamura et al. 2017). Biological effects can be exerted by any of the components of the EVs cargo, whether it is internal or present on the surface of the vesicles (S et al. 2013; Robbins and Morelli, 2014). Therefore, unraveling EVs' exact biological effects is challenging (Lener et al. 2015; Gross et al. 2017). Several preclinical and clinical studies with EVs have shown that human tissue or cell-derived EVs do not per se pose risk in terms of safety concerns. Nevertheless, EVs mediated toxicity cannot be overlooked. It has been reported that EVs cargo may change depending upon the

Table 1 Safety and Efficacy Clinical Trials for EVs in COVID-19 disease

\begin{tabular}{|c|c|c|c|c|c|}
\hline Clinical Phase & Intervention & Status & Trial Identifier & Route of administration & Outcome \\
\hline II & $\begin{array}{l}\text { Bone marrow } \\
\text { MSCs-EVs } \\
\left(\text { ExoFlo }^{\mathrm{TM}}\right)\end{array}$ & Not recruiting & $\begin{array}{l}\text { NCT04493242 } \\
\text { (EXIT COVID-19) }\end{array}$ & Intravenous & -- \\
\hline Access & $\begin{array}{l}\text { Bone marrow } \\
\text { MSCs-EVs } \\
\left(\text { ExoFlo }^{\mathrm{TM}}\right)\end{array}$ & Active & NCT04657458 & Intravenous & -- \\
\hline-- & $\begin{array}{l}\text { Cardiosphere-EVs } \\
\text { (CAP-1002) }\end{array}$ & Inactive & NCT04338347 & Intravenous & -- \\
\hline I & $\mathrm{T}$ cell exosomes & Not & $\begin{array}{l}\text { NCT04389385 } \\
\text { (CSTC-Exo) }\end{array}$ & Aerosol & -- \\
\hline I \& II & Amniotic fluid EVs (Zofin $\left.{ }^{\mathrm{TM}}\right)$ & recruiting & NCT04384445 & Intravenous & -- \\
\hline I & Adipose MCSs & Recruiting & NCT04276987 & Aerosol & -- \\
\hline I \& II & MSCs (EXO1 and EXO2) & Complete & $\begin{array}{l}\text { NCT04491240 } \\
\text { (COVID-19EXO) }\end{array}$ & Aerosol & -- \\
\hline
\end{tabular}


surrounding microenvironment or toxic stimulants. Such EVs with altered biological cargo when enter the target cells and tissues and affect ongoing pathological processes (Rokad et al. 2019). Therefore, complete compliance with the established guidelines is necessary to ensure EVs safety for any clinical intervention (Wiklander et al. 2015).

Currently, there is no EV isolation technique for effective large-scale manufacturing of EVs, making clinical translation of EV-based therapeutics difficult (Greening et al. 2015; Lobb et al. 2015). Conventional twodimensional and three-dimensional culture techniques are employed for the maintenance and expansion of EVs (Whitford et al. 2015; Colao et al. 2018), while size exclusion chromatography and ultracentrifugation methods are used for purification (Mol et al. 2017; Monguio-Tortajada et al. 2019). Perfection of such techniques for large-scale GMP-compliant is challenging (Ludwig et al. 2019). Additionally, EVs isolation and purification method influence their yield, purity, size distribution, and cargo composition (Tang et al. 2017; Stranska et al. 2018). EVs from an autologous source are generally used for clinical studies which further influence the scalability and ultimate cost of EV therapies (Lener et al. 2015). Storage conditions can affect EVs' integrity. EVs can form aggregates due to $\mathrm{pH}$ changes (Larson et al. 2013), interact with storage vials, as well as be affected by freezing and thawing procedures (Lorincz et al. 2014). Unfortunately, there are no studies and standardized protocol assessing the effects of storage temperature and times on the EV's stability and functionality (Thery et al. 2018). Although, preclinical studies have demonstrated immense therapeutic potential of EVs, their clinical translatability is a major challenge (Robbins and Morelli, 2014). As a result, till date, no single EV therapy has been approved for marketing which make such candidate difficulty to get regulatory approval.

\section{Conclusions}

Despite the challenges associated with the use of EVs as therapeutics, due to favorable biological properties and ability to serve as natural carrier for small molecules, EVs are still candidate choice for the vaccine development. Existing EV isolation and purification strategies can be employed with the maximum potential to comply with cGMP requirements. The International Society for Cellular and Gene Therapies and the International Society for Extracellular Vesicles recently published a statement to encourage development of EVs based therapeutics from MSCs and other cells for the treatment of COVID-19 but with strict regulatory measures (Borger et al. 2020).

\section{References}

Abels ER, Breakefield XO (2016) Introduction to extracellular vesicles: biogenesis, RNA cargo selection, content, release, and uptake. Cell Mol Neurobiol 36:301-312

Ahn SY, Park WS, Kim YE, Sung DK, Sung SI, Ahn JY, Chang YS (2018) Vascular endothelial growth factor mediates the therapeutic efficacy of mesenchymal stem cell-derived extracellular vesicles against neonatal hyperoxic lung injury. Exp Mol Med 50:26

Akers JC, Gonda D, Kim R, Carter BS, Chen CC (2013) Biogenesis of extracellular vesicles (EV): exosomes, microvesicles, retrovirus-like vesicles, and apoptotic bodies. J Neurooncol 113:1-11

Ali SA, Huang MB, Campbell PE, Roth WW, Campbell T, Khan M, Newman G, Villinger F, Powell MD, Bond VC (2010) Genetic characterization of HIV type 1 Nef-induced vesicle secretion. AIDS Res Hum Retrovir 26:173-192

Alvarez-Erviti L, Seow Y, Yin H, Betts C, Lakhal S, Wood MJ (2011) Delivery of siRNA to the mouse brain by systemic injection of targeted exosomes. Nat Biotechnol 29:341-345

Alzahrani FA, Saadeldin IM, Ahmad A, Kumar D, Azhar EI, Siddiqui AJ, Kurdi B, Sajini A, Alrefaei AF, Jahan S (2020) The potential use of mesenchymal stem cells and their derived exosomes as immunomodulatory agents for COVID-19 patients. Stem Cells Int 2020: 8835986

Anderson MR, Kashanchi F, Jacobson S (2016) Exosomes in viral disease. Neurotherapeutics 13:535-546

Anticoli S, Manfredi F, Chiozzini C, Arenaccio C, Olivetta E, Ferrantelli F, Capocefalo A, Falcone E, Ruggieri A, Federico M (2018) An exosome-based vaccine platform imparts cytotoxic T lymphocyte immunity against viral antigens. Biotechnol J 13:e1700443

Ariza ME, Rivailler P, Glaser R, Chen M, Williams MV (2013) EpsteinBarr virus encoded dUTPase containing exosomes modulate innate and adaptive immune responses in human dendritic cells and peripheral blood mononuclear cells. PLoS One 8:e69827

Atay S, Gercel-Taylor C, Taylor DD (2011) Human trophoblast-derived exosomal fibronectin induces pro-inflammatory IL-1beta production by macrophages. Am J Reprod Immunol 66:259-269

Badierah RA, Uversky VN, Redwan EM (2020) Dancing with Trojan horses: an interplay between the extracellular vesicles and viruses. J Biomol Struct Dyn:1-27

Barbulescu M, Turner G, Seaman MI, Deinard AS, Kidd KK, Lenz J (1999) Many human endogenous retrovirus K (HERV-K) proviruses are unique to humans. Curr Biol 9:861-868

Bari E, Ferrarotti I, Saracino L, Perteghella S, Torre ML, Corsico AG (2020) Mesenchymal stromal cell secretome for severe COVID-19 infections: premises for the therapeutic use. Cells 9:924

Barres C, Blanc L, Bette-Bobillo P, Andre S, Mamoun R, Gabius HJ, Vidal M (2010) Galectin-5 is bound onto the surface of rat reticulocyte exosomes and modulates vesicle uptake by macrophages. Blood 115:696-705

Barry OP, Pratico D, Savani RC, FitzGerald GA (1998) Modulation of monocyte-endothelial cell interactions by platelet microparticles. J Clin Invest 102:136-144

Battistelli M, Falcieri E (2020) Apoptotic bodies: particular extracellular vesicles involved in intercellular communication. Biology (Basel) 9(1):21

Benedikter BJ, Bouwman FG, Vajen T, Heinzmann ACA, Grauls G, Mariman EC, Wouters EFM, Savelkoul PH, Lopez-Iglesias C, Koenen RR, Rohde GGU, Stassen FRM (2017) Ultrafiltration combined with size exclusion chromatography efficiently isolates extracellular vesicles from cell culture media for compositional and functional studies. Sci Rep 7:15297

Bernard O, Jeny F, Uzunhan Y, Dondi E, Terfous R, Label R, Sutton A, Larghero J, Vanneaux V, Nunes H, Boncoeur E, Planes C, Dard N 
(2018) Mesenchymal stem cells reduce hypoxia-induced apoptosis in alveolar epithelial cells by modulating HIF and ROS hypoxic signaling. Am J Physiol Lung Cell Mol Physiol 314:L360-L371

Bhatnagar S, Shinagawa K, Castellino FJ, Schorey JS (2007) Exosomes released from macrophages infected with intracellular pathogens stimulate a proinflammatory response in vitro and in vivo. Blood 110:3234-3244

Bhattacharya J, Matthay MA (2013) Regulation and repair of the alveolar-capillary barrier in acute lung injury. Annu Rev Physiol 75:593-615

Bhome R, Del Vecchio F, Lee GH, Bullock MD, Primrose JN, Sayan AE, Mirnezami AH (2018) Exosomal microRNAs (exomiRs): Small molecules with a big role in cancer. Cancer Lett 420:228-235

Bian P, Ye C, Zheng X, Yang J, Ye W, Wang Y, Zhou Y, Ma H, Han P, Zhang H, Zhang Y, Zhang F, Lei Y, Jia Z (2017) Mesenchymal stem cells alleviate Japanese encephalitis virus-induced neuroinflammation and mortality. Stem Cell Res Ther 8:38

BioPharma-Reporter (2020) Regeneron's COVID-19 antibody cocktail receives EUA from FDA. https://www.biopharma-reporter.com/ Article/2020/11/23/Regeneron-s-COVID-19-antibody-cocktailreceives-EUA-from-FDA

Bock M, Stoye JP (2000) Endogenous retroviruses and the human germline. Curr Opin Genet Dev 10:651-655

Booth AM, Fang Y, Fallon JK, Yang JM, Hildreth JE, Gould SJ (2006) Exosomes and HIV Gag bud from endosome-like domains of the T cell plasma membrane. J Cell Biol 172:923-935

Borger V et al (2020) International Society for Extracellular Vesicles and International Society for Cell and Gene Therapy statement on extracellular vesicles from mesenchymal stromal cells and other cells: considerations for potential therapeutic agents to suppress coronavirus disease-19. Cytotherapy 22:482-485

Börger V, Dittrich R, Staubach S, Zumegen S, Horn P, Giebel B (2019) Tangential flow filtration, a potential method for the scaled preparation of extracellular vesicles. Cytotherapy 21:S57

Brown C, McKee C, Bakshi S, Walker K, Hakman E, Halassy S, Svinarich D, Dodds R, Govind CK, Chaudhry GR (2019) Mesenchymal stem cells: Cell therapy and regeneration potential. J Tissue Eng Regen Med 13:1738-1755

Brown L, Wolf JM, Prados-Rosales R, Casadevall A (2015) Through the wall: extracellular vesicles in Gram-positive bacteria, mycobacteria and fungi. Nat Rev Microbiol 13:620-630

Cai C, Koch B, Morikawa K, Suda G, Sakamoto N, Rueschenbaum S, Akhras S, Dietz J, Hildt E, Zeuzem S, Welsch C, Lange CM (2018) Macrophage-derived extracellular vesicles induce long-lasting immunity against hepatitis $C$ virus which is blunted by polyunsaturated fatty acids. Front Immunol 9:723

Cantin R, Diou J, Bélanger D, Tremblay AM, Gilbert C (2008) Discrimination between exosomes and HIV-1: Purification of both vesicles from cell-free supernatants. J Immunol Methods 338:21-30

Carroll-Portillo A, Surviladze Z, Cambi A, Lidke DS, Wilson BS (2012) Mast cell synapses and exosomes: membrane contacts for information exchange. Front Immunol 3:46

Cha JM, Shin EK, Sung JH, Moon GJ, Kim EH, Cho YH, Park HD, Bae H, Kim J, Bang OY (2018) Efficient scalable production of therapeutic microvesicles derived from human mesenchymal stem cells. Sci Rep 8:1171

Chance TC, Rathbone CR, Kamucheka RM, Peltier GC, Cap AP, Bynum JA (2019) The effects of cell type and culture condition on the procoagulant activity of human mesenchymal stromal cell-derived extracellular vesicles. J Trauma Acute Care Surg 87:S74-S82

Chaturvedi R, Naidu R, Sheth S, Chakravarthy K (2020) Efficacy of Serology testing in predicting reinfection in patients with SARSCoV-2. Disaster Med Public Health Prep:1-3

Chen J, Hu C, Chen L, Tang L, Zhu Y, Xu X, Chen L, Gao H, Lu X, Yu L, Dai X, Xiang C, Li L (2020) Clinical study of mesenchymal stem cell treating acute respiratory distress syndrome induced by epidemic Influenza A (H7N9) infection, a hint for COVID-19 treatment. Engineering (Beijing) 6(10):1153-1161

Christianson HC, Svensson KJ, van Kuppevelt TH, Li JP, Belting M (2013) Cancer cell exosomes depend on cell-surface heparan sulfate proteoglycans for their internalization and functional activity. Proc Natl Acad Sci U S A 110:17380-17385

Chrzanowski W, Kim SY, McClements L (2020) Can stem cells beat COVID-19: advancing stem cells and extracellular vesicles toward mainstream medicine for lung injuries associated with SARS-CoV2 infections. Front Bioeng Biotechnol 8:554

Chung YH, Beiss V, Fiering SN, Steinmetz NF (2020) COVID-19 vaccine frontrunners and their nanotechnology design. ACS Nano 14: 12522-12537

Cintolo JA, Datta J, Mathew SJ, Czerniecki BJ (2012) Dendritic cellbased vaccines: barriers and opportunities. Future Oncol 8:12731299

Colao IL, Corteling R, Bracewell D, Wall I (2018) Manufacturing exosomes: a promising therapeutic platform. Trends Mol Med 24: $242-256$

Combes V, Guillemin GJ, Chan-Ling T, Hunt NH, Grau GE (2012) The crossroads of neuroinflammation in infectious diseases: endothelial cells and astrocytes. Trends Parasitol 28:311-319

ContagionLive (2020) The COVID-19 live vaccine tracker. https://www. contagionlive.com/view/the-covid19-live-vaccine-tracker

Cooper LF, Ravindran S, Huang C-C, Kang M (2020) A role for exosomes in craniofacial tissue engineering and regeneration. Front Physiol 10:1569

Coppin L, Sokal E, Stephenne X (2019) Thrombogenic risk induced by intravascular mesenchymal stem cell therapy: current status and future perspectives. Cells 8(10):1160

Corey L, Mascola JR, Fauci AS, Collins FS (2020) A strategic approach to COVID-19 vaccine R\&D. Science 368:948-950

Costa Verdera H, Gitz-Francois JJ, Schiffelers RM, Vader P (2017) Cellular uptake of extracellular vesicles is mediated by clathrinindependent endocytosis and macropinocytosis. J Control Release 266:100-108

Crenshaw BJ, Gu L, Sims B, Matthews QL (2018) Exosome biogenesis and biological function in response to viral infections. Open Virol J 12:134-148

Cruz FF, Borg ZD, Goodwin M, Sokocevic D, Wagner DE, Coffey A, Antunes M, Robinson KL, Mitsialis SA, Kourembanas S, Thane K, Hoffman AM, McKenna DH, Rocco PR, Weiss DJ (2015) Systemic administration of human bone marrow-derived mesenchymal stromal cell extracellular vesicles ameliorates aspergillus hyphal extractinduced allergic airway inflammation in immunocompetent mice. Stem Cells Transl Med 4:1302-1316

de Jong OG, Kooijmans SAA, Murphy DE, Jiang L, Evers MJW, Sluijter JPG, Vader P, Schiffelers RM (2019) Drug delivery with extracellular vesicles: from imagination to innovation. Acc Chem Res 52: $1761-1770$

Delabranche X, Berger A, Boisrame-Helms J, Meziani F (2012) Microparticles and infectious diseases. Med Mal Infect 42:335-343

Deshmukh V, Motwani R, Kumar A, Kumari C, Raza K (2020) Histopathological observations in COVID-19: a systematic review. J Clin Pathol

Ding M, Wang C, Lu X, Zhang C, Zhou Z, Chen X, Zhang CY, Zen K, Zhang C (2018) Comparison of commercial exosome isolation kits for circulating exosomal microRNA profiling. Anal Bioanal Chem 410:3805-3814

Dominici M, Le Blanc K, Mueller I, Slaper-Cortenbach I, Marini F, Krause D, Deans R, Keating A, Prockop D, Horwitz E (2006) Minimal criteria for defining multipotent mesenchymal stromal cells. The International Society for Cellular Therapy position statement. Cytotherapy 8:315-317

Dreux M, Garaigorta U, Boyd B, Decembre E, Chung J, Whitten-Bauer C, Wieland S, Chisari FV (2012) Short-range exosomal transfer of 
viral RNA from infected cells to plasmacytoid dendritic cells triggers innate immunity. Cell Host Microbe 12:558-570

Elmore S (2007) Apoptosis: a review of programmed cell death. Toxicol Pathol 35:495-516

Elrashdy F, Redwan EM, Uversky VN (2020) Why COVID-19 transmission is more efficient and aggressive than viral transmission in previous coronavirus epidemics? Biomolecules 10(9):1312

Elrashdy F, Aljaddawi AA, Redwan EM, Uversky VN (2020b) On the potential role of exosomes in the COVID-19 reinfection/reactivation opportunity. J Biomol Struct Dyn:1-12

Farkash EA, Wilson AM, Jentzen JM (2020) Ultrastructural evidence for direct renal infection with SARS-CoV-2. J Am Soc Nephrol 31: $1683-1687$

Feng D, Zhao WL, Ye YY, Bai XC, Liu RQ, Chang LF, Zhou Q, Sui SF (2010) Cellular internalization of exosomes occurs through phagocytosis. Traffic 11:675-687

Florindo HF, Kleiner R, Vaskovich-Koubi D, Acurcio RC, Carreira B, Yeini E, Tiram G, Liubomirski Y, Satchi-Fainaro R (2020) Immune-mediated approaches against COVID-19. Nat Nanotechnol 15:630-645

Florl AR, Lower R, Schmitz-Drager BJ, Schulz WA (1999) DNA methylation and expression of LINE-1 and HERV-K provirus sequences in urothelial and renal cell carcinomas. Br J Cancer 80:1312-1321

Fruhbeis C, Frohlich D, Kuo WP, Amphornrat J, Thilemann S, Saab AS, Kirchhoff F, Mobius W, Goebbels S, Nave KA, Schneider A, Simons M, Klugmann M, Trotter J, Kramer-Albers EM (2013) Neurotransmitter-triggered transfer of exosomes mediates oligodendrocyte-neuron communication. PLoS Biol 11:e1001604

Fuhrmann G, Herrmann IK, Stevens MM (2015) Cell-derived vesicles for drug therapy and diagnostics: opportunities and challenges. Nano Today 10:397-409

Fujita Y, Kadota T, Araya J, Ochiya T, Kuwano K (2018) Clinical application of mesenchymal stem cell-derived extracellular vesicle-based therapeutics for inflammatory lung diseases. J Clin Med 7(10):355

Galderisi U, Giordano A (2014) The gap between the physiological and therapeutic roles of mesenchymal stem cells. Med Res Rev 34: $1100-1126$

Gao J, Dong X, Wang Z (2020a) Generation, purification and engineering of extracellular vesicles and their biomedical applications. Methods 177:114-125

Gao Z, Xu Y, Guo Y, Xu D, Zhang L, Wang X, Sun C, Qiu S, Ma K (2020b) A systematic review of re-detectable positive virus nucleic acid among COVID-19 patients in recovery phase. Infect Genet Evol 85:104494

Gardiner C, Di Vizio D, Sahoo S, Théry C, Witwer KW, Wauben M, Hill AF (2016) Techniques used for the isolation and characterization of extracellular vesicles: results of a worldwide survey. J Extracell Vesicles 5:32945-32945

Gilligan KE, Dwyer RM (2017) Engineering exosomes for cancer therapy. Int J Mol Sci 18:1122

Giri PK, Schorey JS (2008) Exosomes derived from M. Bovis BCG infected macrophages activate antigen-specific CD4 + and CD8 + $\mathrm{T}$ cells in vitro and in vivo. PLoS One 3:e2461

Gladnikoff M, Shimoni E, Gov NS, Rousso I (2009) Retroviral assembly and budding occur through an actin-driven mechanism. Biophys J 97:2419-2428

Golan M, Hizi A, Resau JH, Yaal-Hahoshen N, Reichman H, Keydar I, Tsarfaty I (2008) Human endogenous retrovirus (HERV-K) reverse transcriptase as a breast cancer prognostic marker. Neoplasia 10: 521-533

Gorringe AR, Pajon R (2012) Bexsero: a multicomponent vaccine for prevention of meningococcal disease. Hum Vaccin Immunother 8: 174-183

Greening DW, Xu R, Ji H, Tauro BJ, Simpson RJ (2015) A protocol for exosome isolation and characterization: evaluation of ultracentrifugation, density-gradient separation, and immunoaffinity capture methods. In: Posch A (ed) Proteomic profiling: methods and protocols. Springer, New York, pp 179-209

Gross S, Jost N, Hartmann JP (2017) [Approval of clinical trials with biological medicinal products]. Bundesgesundheitsbl Gesundheitsforsch Gesundheitsschutz 60:826-829

Gu J, Korteweg C (2007) Pathology and pathogenesis of severe acute respiratory syndrome. Am J Pathol 170:1136-1147

Guo SC, Tao SC, Yin WJ, Qi X, Yuan T, Zhang CQ (2017) Exosomes derived from platelet-rich plasma promote the re-epithelization of chronic cutaneous wounds via activation of YAP in a diabetic rat model. Theranostics 7:81-96

Gupta N, Krasnodembskaya A, Kapetanaki M, Mouded M, Tan X, Serikov V, Matthay MA (2012) Mesenchymal stem cells enhance survival and bacterial clearance in murine Escherichia coli pneumonia. Thorax 67:533-539

Han C, Sun X, Liu L, Jiang H, Shen Y, Xu X, Li J, Zhang G, Huang J, Lin Z, Xiong N, Wang T (2016) Exosomes and their therapeutic potentials of stem cells. Stem Cells Int 2016:7653489

Han Z, Liu X, Chen X, Zhou X, Du T, Roizman B, Zhou G (2016b) miR$\mathrm{H} 28$ and miR-H29 expressed late in productive infection are exported and restrict HSV-1 replication and spread in recipient cells. Proc Natl Acad Sci U S A 113:E894-E901

Haraszti RA, Miller R, Stoppato M, Sere YY, Coles A, Didiot MC, Wollacott R, Sapp E, Dubuke ML, Li X, Shaffer SA, DiFiglia M, Wang Y, Aronin N, Khvorova A (2018) Exosomes produced from 3D Cultures of MSCs by tangential flow filtration show higher yield and improved activity. Mol Ther 26:2838-2847

Harrell CR, Jovicic N, Djonov V, Arsenijevic N, Volarevic V (2019) Mesenchymal stem cell-derived exosomes and other extracellular vesicles as new remedies in the therapy of inflammatory diseases. Cells 8:1605

Hassanpour M, Rezaie J, Nouri M, Panahi Y (2020) The role of extracellular vesicles in COVID-19 virus infection. Infect Genet Evol 85: $104422-104422$

Hellum M, Ovstebo R, Brusletto BS, Berg JP, Brandtzaeg P, Henriksson CE (2014) Microparticle-associated tissue factor activity correlates with plasma levels of bacterial lipopolysaccharides in meningococcal septic shock. Thromb Res 133:507-514

Helwa I, Cai J, Drewry MD, Zimmerman A, Dinkins MB, Khaled ML, Seremwe M, Dismuke WM, Bieberich E, Stamer WD, Hamrick MW, Liu Y (2017) A comparative study of serum exosome isolation using differential ultracentrifugation and three commercial reagents. PLoS One 12:e0170628

Hess C, Sadallah S, Hefti A, Landmann R, Schifferli JA (1999) Ectosomes released by human neutrophils are specialized functional units. J Immunol 163:4564-4573

Hinger SA, Cha DJ, Franklin JL, Higginbotham JN, Dou Y, Ping J, Shu L, Prasad N, Levy S, Zhang B, Liu Q, Weaver AM, Coffey RJ, Patton JG (2018) Diverse long RNAs are differentially sorted into extracellular vesicles secreted by colorectal cancer cells. Cell Rep 25:715-725 e714

Hoshino A et al (2015) Tumour exosome integrins determine organotropic metastasis. Nature 527:329-335

Hristov M, Erl W, Linder S, Weber PC (2004) Apoptotic bodies from endothelial cells enhance the number and initiate the differentiation of human endothelial progenitor cells in vitro. Blood 104:27612766

Hu Q, Sun W, Wang J, Ruan H, Zhang X, Ye Y, Shen S, Wang C, Lu W, Cheng K, Dotti G, Zeidner JF, Wang J, Gu Z (2018) Conjugation of haematopoietic stem cells and platelets decorated with anti-PD-1 antibodies augments anti-leukaemia efficacy. Nat Biomed Eng 2: $831-840$

Huang W, Wang S, Yao Y, Xia Y, Yang X, Li K, Sun P, Liu C, Sun W, Bai H, Chu X, Li Y, Ma Y (2016) Employing Escherichia coliderived outer membrane vesicles as an antigen delivery platform 
elicits protective immunity against Acinetobacter baumannii infection. Sci Rep 6:37242

Jan AT (2017) Outer Membrane Vesicles (OMVs) of gram-negative bacteria: a perspective update. Front Microbiol 8:1053

Jayaseelan VP (2020) Emerging role of exosomes as promising diagnostic tool for cancer. Cancer Gene Ther 27:395-398

Kadiu I, Narayanasamy P, Dash PK, Zhang W, Gendelman HE (2012) Biochemical and biologic characterization of exosomes and microvesicles as facilitators of HIV-1 infection in macrophages. J Immunol 189:744-754

Kalamvoki M, Du T, Roizman B (2014) Cells infected with herpes simplex virus 1 export to uninfected cells exosomes containing STING, viral mRNAs, and microRNAs. Proc Natl Acad Sci U S A 111: E4991-E4996

Kawamura Y, Yamamoto Y, Sato TA, Ochiya T (2017) Extracellular vesicles as trans-genomic agents: Emerging roles in disease and evolution. Cancer Sci 108:824-830

Khalaj K, Figueira RL, Antounians L, Lauriti G, Zani A (2020) Systematic review of extracellular vesicle-based treatments for lung injury: are EVs a potential therapy for COVID-19? J Extracell Vesicles 9:1795365

Khatri M, Richardson LA, Meulia T (2018) Mesenchymal stem cellderived extracellular vesicles attenuate influenza virus-induced acute lung injury in a pig model. Stem Cell Res Ther 9:17

Khatua AK, Taylor HE, Hildreth JE, Popik W (2009) Exosomes packaging APOBEC $3 \mathrm{G}$ confer human immunodeficiency virus resistance to recipient cells. J Virol 83:512-521

Kim JH, Lee J, Park J, Gho YS (2015a) Gram-negative and Grampositive bacterial extracellular vesicles. Semin Cell Dev Biol 40: 97-104

Kim KM, Abdelmohsen K, Mustapic M, Kapogiannis D, Gorospe M (2017) RNA in extracellular vesicles. Wiley Interdiscip Rev RNA 8

Kim OY, Choi SJ, Jang SC, Park KS, Kim SR, Choi JP, Lim JH, Lee SW, Park J, Di Vizio D, Lotvall J, Kim YK, Gho YS (2015b) Bacterial protoplast-derived nanovesicles as vaccine delivery system against bacterial infection. Nano Lett 15:266-274

Korber B, Fischer WM, Gnanakaran S, Yoon H, Theiler J, Abfalterer W, Foley B, Giorgi EE, Bhattacharya T, Parker MD, Partridge DG, Evans CM, de Silva TI, LaBranche CC, Montefiori DC (2020) Spike mutation pipeline reveals the emergence of a more transmissible form of SARS-CoV-2. bioRxiv:2020.2004.2029.069054

Kouwaki T, Okamoto M, Tsukamoto H, Fukushima Y, Oshiumi H (2017) Extracellular vesicles deliver host and virus RNA and regulate innate immune response. Int J Mol Sci 18(3):666

Krasnodembskaya A, Song Y, Fang X, Gupta N, Serikov V, Lee JW, Matthay MA (2010) Antibacterial effect of human mesenchymal stem cells is mediated in part from secretion of the antimicrobial peptide LL-37. Stem Cells 28:2229-2238

$\mathrm{Ku}$ A, Lim HC, Evander M, Lilja H, Laurell T, Scheding S, Ceder Y (2018) Acoustic enrichment of extracellular vesicles from biological fluids. Anal Chem 90:8011-8019

Kuate S, Cinatl J, Doerr HW, Uberla K (2007) Exosomal vaccines containing the $\mathrm{S}$ protein of the SARS coronavirus induce high levels of neutralizing antibodies. Virology 362:26-37

Kumar S, Zhi K, Mukherji A, Gerth K (2020) Repurposing antiviral protease inhibitors using extracellular vesicles for potential therapy of COVID-19. Viruses 12(5):486

Larson MC, Luthi MR, Hogg N, Hillery CA (2013) Calcium-phosphate microprecipitates mimic microparticles when examined with flow cytometry. Cytometry A 83:242-250

Le Blanc K, Ringden O (2007) Immunomodulation by mesenchymal stem cells and clinical experience. J Intern Med 262:509-525

Lener T et al (2015) Applying extracellular vesicles based therapeutics in clinical trials - an ISEV position paper. J Extracell Vesicles 4:30087
Leng Z et al (2020) Transplantation of ACE2(-) mesenchymal stem cells improves the outcome of patients with COVID-19 pneumonia. Aging Dis 11:216-228

Li F, Wang Y, Lin L, Wang J, Xiao H, Li J, Peng X, Dai H, Li L (2016) Mast cell-derived exosomes promote $\mathrm{Th} 2$ cell differentiation via OX40L-OX40 ligation. J Immunol Res 2016:3623898

Li Q et al (2020a) Early transmission dynamics in Wuhan, China, of Novel Coronavirus-Infected pneumonia. N Engl J Med 382:1199 1207

Li N, Wang X, Lv T (2020b) Prolonged SARS-CoV-2 RNA shedding: Not a rare phenomenon. J Med Virol 92:2286-2287

Li XB, Zhang ZR, Schluesener HJ, Xu SQ (2006) Role of exosomes in immune regulation. J Cell Mol Med 10:364-375

Liang B, Chen J, Li T, Wu H, Yang W, Li Y, Li J, Yu C, Nie F, Ma Z, Yang M, Xiao M, Nie P, Gao Y, Qian C, Hu M (2020) Clinical remission of a critically ill COVID-19 patient treated by human umbilical cord mesenchymal stem cells: A case report. Med (Baltim) 99:e21429

Lima LG, Chammas R, Monteiro RQ, Moreira ME, Barcinski MA (2009) Tumor-derived microvesicles modulate the establishment of metastatic melanoma in a phosphatidylserine-dependent manner. Cancer Lett 283:168-175

Lin J, Li J, Huang B, Liu J, Chen X, Chen X-M, Xu Y-M, Huang L-F, Wang X-Z (2015) Exosomes: novel biomarkers for clinical diagnosis. ScientificWorldJournal 2015:657086-657086

Lindenbergh MFS, Stoorvogel W (2018) Antigen presentation by extracellular vesicles from professional antigen-presenting cells. Annu Rev Immunol 36:435-459

Ling Y, Xu SB, Lin YX, Tian D, Zhu ZQ, Dai FH, Wu F, Song ZG, Huang W, Chen J, Hu BJ, Wang S, Mao EQ, Zhu L, Zhang WH, Lu HZ (2020) Persistence and clearance of viral RNA in 2019 novel coronavirus disease rehabilitation patients. Chin Med J (Engl) 133: 1039-1043

Ling ZL, Combes V, Grau GE, King NJ (2011) Microparticles as immune regulators in infectious disease - an opinion. Front Immunol 2:67

Liu C, Zhou Q, Li Y, Garner LV, Watkins SP, Carter LJ, Smoot J, Gregg AC, Daniels AD, Jervey S, Albaiu D (2020) Research and development on therapeutic agents and vaccines for COVID-19 and related human coronavirus diseases. ACS Cent Sci 6:315-331

Lobb RJ, Becker M, Wen SW, Wong CSF, Wiegmans AP, Leimgruber A, Möller A (2015) Optimized exosome isolation protocol for cell culture supernatant and human plasma. J Extracell Vesicles 4: 27031-27031

Lorincz AM, Timar CI, Marosvari KA, Veres DS, Otrokocsi L, Kittel A, Ligeti E (2014) Effect of storage on physical and functional properties of extracellular vesicles derived from neutrophilic granulocytes. J Extracell Vesicles 3:25465

Ludwig N, Whiteside TL, Reichert TE (2019) Challenges in exosome isolation and analysis in health and disease. Int J Mol Sci 20:4684

Ma Q, Fan Q, Xu J, Bai J, Han X, Dong Z, Zhou X, Liu Z, Gu Z, Wang C (2020) Calming cytokine storm in pneumonia by targeted delivery of TPCA-1 using platelet-derived extracellular vesicles. Matter 3: 287-301

Machhi J, Herskovitz J, Senan AM, Dutta D, Nath B, Oleynikov MD, Blomberg WR, Meigs DD, Hasan M, Patel M, Kline P, Chang RC, Chang L, Gendelman HE, Kevadiya BD (2020) The natural history, pathobiology, and clinical manifestations of SARS-CoV-2 infections. J Neuroimmune Pharmacol

Malkin EZ, Bratman SV (2020) Bioactive DNA from extracellular vesicles and particles. Cell Death Dis 11:584

Man K, Brunet MY, Jones MC, Cox SC (2020) Engineered extracellular vesicles: tailored-made nanomaterials for medical applications. Nanomaterials (Basel) 10(9):1838

Manna I, Iaccino E, Dattilo V, Barone S, Vecchio E, Mimmi S, Filippelli E, Demonte G, Polidoro S, Granata A, Scannapieco S, Quinto I, Valentino P, Quattrone A (2018) Exosome-associated miRNA 
profile as a prognostic tool for therapy response monitoring in multiple sclerosis patients. FASEB J 32:4241-4246

Marshall JS, Portales-Cervantes L, Leong E (2019) Mast cell responses to viruses and pathogen products. Int J Mol Sci 20(17):4241

Matsumoto H, Yamakawa K, Ogura H, Koh T, Matsumoto N, Shimazu T (2015) Enhanced expression of cell-specific surface antigens on endothelial microparticles in sepsis-induced disseminated intravascular coagulation. Shock 43:443-449

Matthay MA, Goolaerts A, Howard JP, Lee JW (2010) Mesenchymal stem cells for acute lung injury: preclinical evidence. Crit Care Med 38:S569-S573

McConnell MJ, Rumbo C, Bou G, Pachon J (2011) Outer membrane vesicles as an acellular vaccine against Acinetobacter baumannii. Vaccine 29:5705-5710

McKee C, Chaudhry GR (2017) Advances and challenges in stem cell culture. Colloids Surf B Biointerfaces 159:62-77

McNamara RP, Caro-Vegas CP, Costantini LM, Landis JT, Griffith JD, Damania BA, Dittmer DP (2018) Large-scale, cross-flow based isolation of highly pure and endocytosis-competent extracellular vesicles. J Extracell Vesicles 7:1541396

McNamara RP, Chugh PE, Bailey A, Costantini LM, Ma Z, Bigi R, Cheves A, Eason AB, Landis JT, Host KM, Xiong J, Griffith JD, Damania B, Dittmer DP (2019) Extracellular vesicles from Kaposi Sarcoma-associated herpesvirus lymphoma induce long-term endothelial cell reprogramming. PLoS Pathog 15:e1007536-e1007536

Mehta P, McAuley DF, Brown M, Sanchez E, Tattersall RS, Manson JJ, Hlh Across Speciality Collaboration UK (2020) COVID-19: consider cytokine storm syndromes and immunosuppression. Lancet 395:1033-1034

Mei SH, Haitsma JJ, Dos Santos CC, Deng Y, Lai PF, Slutsky AS, Liles WC, Stewart DJ (2010) Mesenchymal stem cells reduce inflammation while enhancing bacterial clearance and improving survival in sepsis. Am J Respir Crit Care Med 182:1047-1057

Meng W, He C, Hao Y, Wang L, Li L, Zhu G (2020) Prospects and challenges of extracellular vesicle-based drug delivery system: considering cell source. Drug Deliv 27:585-598

Moderna (2020) Moderna announces primary efficacy analysis in phase 3 COVE Study for Its COVID-19 vaccine candidate and filing today with U.S. FDA for emergency use authorization. https://investors. modernatx.com/news-releases/news-release-details/modernaannounces-primary-efficacy-analysis-phase-3-cove-study/

Mohammadipoor A, Antebi B, Batchinsky AI, Cancio LC (2018) Therapeutic potential of products derived from mesenchymal stem/stromal cells in pulmonary disease. Respir Res 19:218

Mol EA, Goumans MJ, Doevendans PA, Sluijter JPG, Vader P (2017) Higher functionality of extracellular vesicles isolated using sizeexclusion chromatography compared to ultracentrifugation. Nanomedicine 13:2061-2065

Monguio-Tortajada M, Galvez-Monton C, Bayes-Genis A, Roura S, Borras FE (2019) Extracellular vesicle isolation methods: rising impact of size-exclusion chromatography. Cell Mol Life Sci 76:23692382

Montaner-Tarbes S, Borras FE, Montoya M, Fraile L, Del Portillo HA (2016) Serum-derived exosomes from non-viremic animals previously exposed to the porcine respiratory and reproductive virus contain antigenic viral proteins. Vet Res 47:59

Montecalvo A, Larregina AT, Shufesky WJ, Stolz DB, Sullivan ML, Karlsson JM, Baty CJ, Gibson GA, Erdos G, Wang Z, Milosevic J, Tkacheva OA, Divito SJ, Jordan R, Lyons-Weiler J, Watkins SC, Morelli AE (2012) Mechanism of transfer of functional microRNAs between mouse dendritic cells via exosomes. Blood 119:756-766

Mooberry MJ, Bradford R, Hobl EL, Lin FC, Jilma B, Key NS (2016) Procoagulant microparticles promote coagulation in a factor XIdependent manner in human endotoxemia. J Thromb Haemost 14: $1031-1042$
Mostefai HA, Bourget JM, Meziani F, Martinez MC, Leonetti D, Mercat A, Asfar P, Germain L, Andriantsitohaina R (2013) Interleukin-10 controls the protective effects of circulating microparticles from patients with septic shock on tissue-engineered vascular media. Clin Sci (Lond) 125:77-85

Mulcahy LA, Pink RC, Carter DR (2014) Routes and mechanisms of extracellular vesicle uptake. J Extracell Vesicles 3

Muraca M, Pessina A, Pozzobon M, Dominici M, Galderisi U, Lazzari L, Parolini O, Lucarelli E, Perilongo G, Baraldi E (2020) Mesenchymal stromal cells and their secreted extracellular vesicles as therapeutic tools for COVID-19 pneumonia? J Control Release 325:135-140

Nasiri Kenari A, Cheng L, Hill AF (2020) Methods for loading therapeutics into extracellular vesicles and generating extracellular vesicles mimetic-nanovesicles. Methods 177:103-113

Nedaeinia R, Manian M, Jazayeri MH, Ranjbar M, Salehi R, Sharifi M, Mohaghegh F, Goli M, Jahednia SH, Avan A, Ghayour-Mobarhan M (2017) Circulating exosomes and exosomal microRNAs as biomarkers in gastrointestinal cancer. Cancer Gene Ther 24:48-56

Ni Z, Zhou S, Li S, Kuang L, Chen H, Luo X, Ouyang J, He M, Du X, Chen L (2020) Exosomes: roles and therapeutic potential in osteoarthritis. Bone Res 8:25

Nieuwland R, Berckmans RJ, McGregor S, Boing AN, Romijn FP, Westendorp RG, Hack CE, Sturk A (2000) Cellular origin and procoagulant properties of microparticles in meningococcal sepsis. Blood 95:930-935

Nordin JZ, Lee Y, Vader P, Mager I, Johansson HJ, Heusermann W, Wiklander OP, Hallbrink M, Seow Y, Bultema JJ, Gilthorpe J, Davies T, Fairchild PJ, Gabrielsson S, Meisner-Kober NC, Lehtio J, Smith CI, Wood MJ, El Andaloussi S (2015) Ultrafiltration with size-exclusion liquid chromatography for high yield isolation of extracellular vesicles preserving intact biophysical and functional properties. Nanomedicine 11:879-883

O'Driscoll L (2020) Extracellular vesicles from mesenchymal stem cells as a Covid-19 treatment. Drug Discov Today 25:1124-1125

Patters BJ, Kumar S (2018) The role of exosomal transport of viral agents in persistent HIV pathogenesis. Retrovirology 15:79

Pedrazza L, Cunha AA, Luft C, Nunes NK, Schimitz F, Gassen RB, Breda RV, Donadio MV, de Souza Wyse AT, Pitrez PMC, Rosa JL, de Oliveira JR (2017) Mesenchymal stem cells improves survival in LPS-induced acute lung injury acting through inhibition of NETs formation. J Cell Physiol 232:3552-3564

Pegtel DM, Cosmopoulos K, Thorley-Lawson DA, van Eijndhoven MA, Hopmans ES, Lindenberg JL, de Gruijl TD, Wurdinger T, Middeldorp JM (2010) Functional delivery of viral miRNAs via exosomes. Proc Natl Acad Sci U S A 107:6328-6333

Petrik J (2016) Immunomodulatory effects of exosomes produced by virus-infected cells. Transfus Apher Sci 55:84-91

Pharmaceutical Business Review (2020) Canada has approved Pfizer and BioNTech's mRNA vaccine BNT162b2 for the prevention of Covid-19. https://www.pharmaceutical-business-review.com/news/ canada-approves-bnt162b2-covid-19/

Pincetic A, Leis J (2009) The mechanism of budding of retroviruses from cell membranes. Adv Virol 2009:6239691-6239699

Pitt JM, Kroemer G, Zitvogel L (2016) Extracellular vesicles: masters of intercellular communication and potential clinical interventions. J Clin Invest 126:1139-1143

Plazolles N, Humbert JM, Vachot L, Verrier B, Hocke C, Halary F (2011) Pivotal advance: The promotion of soluble DC-SIGN release by inflammatory signals and its enhancement of cytomegalovirusmediated cis-infection of myeloid dendritic cells. J Leukoc Biol 89:329-342

Pocsfalvi G, Mammadova R, Ramos Juarez AP, Bokka R, Trepiccione F, Capasso G (2020) COVID-19 and extracellular vesicles: an intriguing interplay. Kidney Blood Press Res 45:661-670

PR Newswire (2020) Direct biologics granted expanded access by FDA for $\mathrm{ExoFlo}^{\mathrm{TM}}$ in the treatment of COVID-19. https://www. 
prnewswire.com/news-releases/direct-biologics-granted-expandedaccess-by-fda-for-exoflo-in-the-treatment-of-covid-19-301151620. $\mathrm{html}$

Raab-Traub N, Dittmer DP (2017) Viral effects on the content and function of extracellular vesicles. Nat Rev Microbiol 15:559-572

Ramachandra L, Qu Y, Wang Y, Lewis CJ, Cobb BA, Takatsu K, Boom WH, Dubyak GR, Harding CV (2010) Mycobacterium tuberculosis synergizes with ATP to induce release of microvesicles and exosomes containing major histocompatibility complex class II molecules capable of antigen presentation. Infect Immun 78:5116-5125

Raposo G, Stoorvogel W (2013) Extracellular vesicles: exosomes, microvesicles, and friends. J Cell Biol 200:373-383

Raymond AD, Campbell-Sims TC, Khan M, Lang M, Huang MB, Bond VC, Powell MD (2011) HIV Type 1 Nef is released from infected cells in CD45(+) microvesicles and is present in the plasma of HIVinfected individuals. AIDS Res Hum Retrovir 27:167-178

Reiche J, Pauli G, Ellerbrok H (2010) Differential expression of human endogenous retrovirus $\mathrm{K}$ transcripts in primary human melanocytes and melanoma cell lines after UV irradiation. Melanoma Res 20: 435-440

Rekker K, Saare M, Roost AM, Kubo AL, Zarovni N, Chiesi A, Salumets A, Peters M (2014) Comparison of serum exosome isolation methods for microRNA profiling. Clin Biochem 47:135-138

Robbins PD, Morelli AE (2014) Regulation of immune responses by extracellular vesicles. Nat Rev Immunol 14:195-208

Robbins PD, Dorronsoro A, Booker CN (2016) Regulation of chronic inflammatory and immune processes by extracellular vesicles. J Clin Invest 126:1173-1180

Rodrigues M, Fan J, Lyon C, Wan M, Hu Y (2018) Role of extracellular vesicles in viral and bacterial infections: pathogenesis, diagnostics, and therapeutics. Theranostics 8:2709-2721

Rojas M, Rodriguez Y, Monsalve DM, Acosta-Ampudia Y, Camacho B, Gallo JE, Rojas-Villarraga A, Ramirez-Santana C, Diaz-Coronado JC, Manrique R, Mantilla RD, Shoenfeld Y, Anaya JM (2020) Convalescent plasma in Covid-19: Possible mechanisms of action. Autoimmun Rev 19:102554

Rokad D, Jin H, Anantharam V, Kanthasamy A, Kanthasamy AG (2019) Exosomes as mediators of chemical-induced toxicity. Curr Environ Health Rep 6:73-79

Russell JH (1995) Activation-induced death of mature T cells in the regulation of immune responses. Curr Opin Immunol 7:382-388

S ELA, Mager I, Breakefield I, Wood XO (2013) Extracellular vesicles: biology and emerging therapeutic opportunities. Nat Rev Drug Discov 12:347-357

Sarich VM (1972) On the nonidentity of several carnivore hemoglobins. Biochem Genet 7:253-258

Schneider D, Smith K, Speth J, Wilke C, Lyons D, Penke L, Lauring A, Moore B, Peters-Golden M (2020a) Mechanisms of alveolar macrophage derived extracellular vesicle defense against influenza infection of alveolar epithelial cells. In: D70. REVISITING LUNG INFECTION AND INFLAMMATORY AXES, pp A7425-A7425: American Thoracic Society, New York

Schneider DJ, Smith KA, Latuszek CE, Wilke CA, Lyons DM, Penke LR, Speth JM, Marthi M, Swanson JA, Moore BB, Lauring AS, Peters-Golden M (2020b) Alveolar macrophage-derived extracellular vesicles inhibit endosomal fusion of influenza virus. EMBO J 39: e105057

Schorey JS, Harding CV (2016) Extracellular vesicles and infectious diseases: new complexity to an old story. J Clin Invest 126:11811189

Schorey JS, Cheng Y, Singh PP, Smith VL (2015) Exosomes and other extracellular vesicles in host-pathogen interactions. EMBO Rep 16: $24-43$

Schwab A, Meyering SS, Lepene B, Iordanskiy S, van Hoek ML, Hakami RM, Kashanchi F (2015) Extracellular vesicles from infected cells: potential for direct pathogenesis. Front Microbiol 6:1132
Sengupta V, Sengupta S, Lazo A, Woods P, Nolan A, Bremer N (2020) Exosomes derived from bone marrow mesenchymal stem cells as treatment for severe COVID-19. Stem Cells Dev 29:747-754

Shahjin F, Chand S, Yelamanchili SV (2019) Extracellular vesicles as drug delivery vehicles to the central nervous system. J Neuroimmune Pharmacol 15(3):443-458

Shi A, Kasumova GG, Michaud WA, Cintolo-Gonzalez J, Diaz-Martinez M, Ohmura J, Mehta A, Chien I, Frederick DT, Cohen S, Plana D, Johnson D, Flaherty KT, Sullivan RJ, Kellis M, Boland GM (2020) Plasma-derived extracellular vesicle analysis and deconvolution enable prediction and tracking of melanoma checkpoint blockade outcome. Sci Adv 6

Shu L, Niu C, Li R, Huang T, Wang Y, Huang M, Ji N, Zheng Y, Chen X, Shi L, Wu M, Deng K, Wei J, Wang X, Cao Y, Yan J, Feng G (2020) Treatment of severe COVID-19 with human umbilical cord mesenchymal stem cells. Stem Cell Res Ther 11:361

Singh M, Chakrapani A, O'Hagan D (2007) Nanoparticles and microparticles as vaccine-delivery systems. Expert Rev Vaccines 6:797-808

Singh PP, LeMaire C, Tan JC, Zeng E, Schorey JS (2011) Exosomes released from $M$. tuberculosis infected cells can suppress IFNgamma mediated activation of naive macrophages. PLoS One 6: e18564

Soares AR, Martins-Marques T, Ribeiro-Rodrigues T, Ferreira JV, Catarino S, Pinho MJ, Zuzarte M, Isabel Anjo S, Manadas B, Pereira JPGS, Girao PH (2015) Gap junctional protein Cx43 is involved in the communication between extracellular vesicles and mammalian cells. Sci Rep 5:13243

Soriano AO, Jy W, Chirinos JA, Valdivia MA, Velasquez HS, Jimenez JJ, Horstman LL, Kett DH, Schein RM, Ahn YS (2005) Levels of endothelial and platelet microparticles and their interactions with leukocytes negatively correlate with organ dysfunction and predict mortality in severe sepsis. Crit Care Med 33:2540-2546

Srour N, Thebaud B (2015) Mesenchymal stromal cells in animal bleomycin pulmonary fibrosis models: a systematic review. Stem Cells Transl Med 4:1500-1510

Stein JM, Luzio JP (1991) Ectocytosis caused by sublytic autologous complement attack on human neutrophils. The sorting of endogenous plasma-membrane proteins and lipids into shed vesicles. Biochem J 274(Pt 2):381-386

Stranska R, Gysbrechts L, Wouters J, Vermeersch P, Bloch K, Dierickx D, Andrei G, Snoeck R (2018) Comparison of membrane affinitybased method with size-exclusion chromatography for isolation of exosome-like vesicles from human plasma. J Transl Med 16:1

Su H, Yang M, Wan C, Yi LX, Tang F, Zhu HY, Yi F, Yang HC, Fogo AB, Nie X, Zhang C (2020) Renal histopathological analysis of 26 postmortem findings of patients with COVID-19 in China. Kidney Int 98:219-227

Tang Y-T, Huang Y-Y, Zheng L, Qin S-H, Xu X-P, An T-X, Xu Y, Wu Y-S, Hu X-M, Ping B-H, Wang Q (2017) Comparison of isolation methods of exosomes and exosomal RNA from cell culture medium and serum. Int J Mol Med 40:834-844

Tao SC, Yuan T, Rui BY, Zhu ZZ, Guo SC, Zhang CQ (2017) Exosomes derived from human platelet-rich plasma prevent apoptosis induced by glucocorticoid-associated endoplasmic reticulum stress in rat osteonecrosis of the femoral head via the $\mathrm{Akt} / \mathrm{Bad} / \mathrm{Bcl}-2$ signal pathway. Theranostics 7:733-750

Taruscio D, Mantovani A (2004) Factors regulating endogenous retroviral sequences in human and mouse. Cytogenet Genome Res 105: 351-362

Thanh Le T, Andreadakis Z, Kumar A, Gomez Roman R, Tollefsen S, Saville M, Mayhew S (2020) The COVID-19 vaccine development landscape. Nat Rev Drug Discov 19:305-306

Thery C, Ostrowski M, Segura E (2009) Membrane vesicles as conveyors of immune responses. Nat Rev Immunol 9:581-593

Thery $\mathrm{C}$ et al (2018) Minimal information for studies of extracellular vesicles 2018 (MISEV2018): a position statement of the 
International Society for Extracellular Vesicles and update of the MISEV2014 guidelines. J Extracell Vesicles 7:1535750

Thippabhotla S, Zhong C, He M (2019) 3D cell culture stimulates the secretion of in vivo like extracellular vesicles. Sci Rep 9:13012

Tian T, Zhu YL, Zhou YY, Liang GF, Wang YY, Hu FH, Xiao ZD (2014) Exosome uptake through clathrin-mediated endocytosis and macropinocytosis and mediating miR-21 delivery. J Biol Chem 289:22258-22267

Tsai M, Grimbaldeston M, Galli SJ (2011) Mast cells and immunoregulation/immunomodulation. In: Mast Cell Biology. Springer, Berlin, pp 186-211

Tsiapalis D, O’Driscoll L (2020) Mesenchymal stem cell derived extracellular vesicles for tissue engineering and regenerative medicine applications. Cells 9(4):991

Urbanelli L, Buratta S, Tancini B, Sagini K, Delo F, Porcellati S, Emiliani C (2019) The role of extracellular vesicles in viral infection and transmission. Vaccines (Basel) 7(3):102

Food US and Drug Administration (USFDA) (2020) FDA takes key action in fight against COVID-19 by issuing emergency use authorization for First COVID-19 vaccine. https://www.fda.gov/newsevents/press-announcements/fda-takes-key-action-fight-againstcovid-19-issuing-emergency-use-authorization-first-covid-19

Vader P, Mol EA, Pasterkamp G, Schiffelers RM (2016) Extracellular vesicles for drug delivery. Adv Drug Deliv Rev 106:148-156

Vagner T, Spinelli C, Minciacchi VR, Balaj L, Zandian M, Conley A, Zijlstra A, Freeman MR, Demichelis F, De S, Posadas EM, Tanaka H, Di Vizio D (2018) Large extracellular vesicles carry most of the tumour DNA circulating in prostate cancer patient plasma. J Extracell Vesicles 7:1505403

Vallhov H, Gutzeit C, Johansson SM, Nagy N, Paul M, Li Q, Friend S, George TC, Klein E, Scheynius A, Gabrielsson S (2011) Exosomes containing glycoprotein 350 released by EBV-transformed B cells selectively target B cells through CD21 and block EBV infection in vitro. J Immunol 186:73-82

Votteler J, Sundquist WI (2013) Virus budding and the ESCRT pathway. Cell Host Microbe 14:232-241

Wang C, Sun W, Ye Y, Hu Q, Bomba HN, Gu Z (2017) In situ activation of platelets with checkpoint inhibitors for post-surgical cancer immunotherapy. Nat Biomed Eng 1:1-10

Wang J, Chen S, Bihl J (2020) Exosome-mediated transfer of ACE2 (Angiotensin-Converting Enzyme 2) from endothelial progenitor cells promotes survival and function of endothelial cell. Oxid Med Cell Longev 2020:4213541-4213541

Wang J, Teng Y, Zhao G, Li F, Hou A, Sun B, Kong W, Gao F, Cai L, Jiang C (2019) Exosome-mediated delivery of inducible miR-423$5 p$ enhances resistance of MRC-5 cells to rabies virus infection. Int J Mol Sci 20(7):1537

Wang W, Xu Y, Gao R, Lu R, Han K, Wu G, Tan W (2020) Detection of SARS-CoV-2 in different types of clinical specimens. JAMA 323(18): 1843-1844

Wassmer SC, Combes V, Grau GER (2011) Platelets and microparticles in cerebral malaria: the unusual suspects. Drug Discov Today Dis Mech 8:e15-e23

Whitford W, Ludlow JW, Cadwell JJS (2015) Continuous production of exosomes. Genet Eng Biotechnol News 35:34-34

Wiklander OP, Nordin JZ, O'Loughlin A, Gustafsson Y, Corso G, Mager I, Vader P, Lee Y, Sork H, Seow Y, Heldring N, Alvarez-Erviti L,
Smith CI, Le Blanc K, Macchiarini P, Jungebluth P, Wood MJ, Andaloussi SE (2015) Extracellular vesicle in vivo biodistribution is determined by cell source, route of administration and targeting. $\mathrm{J}$ Extracell Vesicles 4:26316

Willis GR, Fernandez-Gonzalez A, Anastas J, Vitali SH, Liu X, Ericsson M, Kwong A, Mitsialis SA, Kourembanas S (2018) Mesenchymal stromal cell exosomes ameliorate experimental bronchopulmonary dysplasia and restore lung function through macrophage immunomodulation. Am J Respir Crit Care Med 197:104-116

Xi Y (2020) Convalescent plasma therapy for COVID-19: a tried-andtrue old strategy? Signal Transduct Target Ther 5:203

Yanez-Mo M et al (2015) Biological properties of extracellular vesicles and their physiological functions. J Extracell Vesicles 4:27066

Ye G, Pan Z, Pan Y, Deng Q, Chen L, Li J, Li Y, Wang X (2020) Clinical characteristics of severe acute respiratory syndrome coronavirus 2 reactivation. J Infect 80:e14-e17

Yi T, Song SU (2012) Immunomodulatory properties of mesenchymal stem cells and their therapeutic applications. Arch Pharm Res 35: 213-221

Yoder JA, Walsh CP, Bestor TH (1997) Cytosine methylation and the ecology of intragenomic parasites. Trends Genet 13:335-340

Yogev O, Henderson S, Hayes MJ, Marelli SS, Ofir-Birin Y, RegevRudzki N, Herrero J, Enver T (2017) Herpesviruses shape tumour microenvironment through exosomal transfer of viral microRNAs. PLoS Pathog 13:e1006524-e1006524

Yu X, Odenthal M, Fries JW (2016) Exosomes as miRNA carriers: formation-function-future. Int J Mol Sci 17(12):2028

Yuan J, Kou S, Liang Y, Zeng J, Pan Y, Liu L (2020) PCR assays turned positive in 25 Discharged COVID-19 Patients. Clin Infect Dis

Zeng Z, Xu L, Xie XY, Yan HL, Xie BJ, Xu WZ, Liu XA, Kang GJ, Jiang WL, Yuan JP (2020) Pulmonary pathology of early phase COVID-19 pneumonia in a patient with a benign lung lesion. Histopathology 77(5):823-831

Zepeda-Cervantes J, Ramirez-Jarquin JO, Vaca L (2020) Interaction between Virus-Like Particles (VLPs) and Pattern Recognition Receptors (PRRs) from Dendritic Cells (DCs): toward better engineering of VLPs. Front Immunol 11:1100

Zeringer E, Barta T, Li M, Vlassov AV (2015) Strategies for isolation of exosomes. Cold Spring Harb Protoc 2015:pdb.top074476

Zhen G, Liu H, Gu N, Zhang H, Xu Y, Zhang Z (2008) Mesenchymal stem cells transplantation protects against rat pulmonary emphysema. Front Biosci 13:3415-3422

Zhou F, Yu T, Du R, Fan G, Liu Y, Liu Z, Xiang J, Wang Y, Song B, Gu X, Guan L, Wei Y, Li H, Wu X, Xu J, Tu S, Zhang Y, Chen H, Cao B (2020) Clinical course and risk factors for mortality of adult inpatients with COVID-19 in Wuhan, China: a retrospective cohort study. Lancet 395:1054-1062

Zhou Y, Zhang Y, Yao Z, Moorman JP, Jia Z (2012) Dendritic cell-based immunity and vaccination against hepatitis $\mathrm{C}$ virus infection. Immunology 136:385-396

Zomer A, Vendrig T, Hopmans ES, van Eijndhoven M, Middeldorp JM, Pegtel DM (2010) Exosomes: Fit to deliver small RNA. Commun Integr Biol 3:447-450

Publisher's note Springer Nature remains neutral with regard to jurisdictional claims in published maps and institutional affiliations. 